Article

\title{
Catalytic Hydrogenation, Hydrodeoxygenation, and Hydrocracking Processes of a Lignin Monomer Model Compound Eugenol over Magnetic $\mathrm{Ru} / \mathrm{C}-\mathrm{Fe}_{2} \mathrm{O}_{3}$ and Mechanistic Reaction Microkinetics
}

\author{
Ana Bjelić ${ }^{1,2}$, Miha Grilc ${ }^{1, *(\mathbb{D})}$, Sašo Gyergyek ${ }^{3}$, Andraž Kocjan ${ }^{4}\left(\mathbb{D}\right.$, Darko Makovec ${ }^{3}$ (i) \\ and Blaž Likozar ${ }^{1}$ \\ 1 Department of Catalysis and Chemical Reaction Engineering, National Institute of Chemistry, Hajdrihova 19, \\ 1001 Ljubljana, Slovenia; ana.bjelic@ki.si (A.B.); blaz.likozar@ki.si (B.L.) \\ 2 Faculty of Chemistry and Chemical Technology, University Ljubljana, Večna pot 113, \\ 1001 Ljubljana, Slovenia \\ 3 Department of Synthesis of Materials, Jožef Stefan Institute, Jamova Cesta 39, 1001 Ljubljana, Slovenia; \\ saso.gyergyek@ijs.si (S.G.); darko.makovec@ijs.si (D.M.) \\ 4 Department of Nanostructured Materials, Jožef Stefan Institute, Jamova Cesta 39, 1001 Ljubljana, Slovenia; \\ andraz.kocjan@ijs.si \\ * Correspondence: miha.grilc@ki.si; Tel.: +386-1-4760-283
}

Received: 13 September 2018; Accepted: 25 September 2018; Published: 28 September 2018

\begin{abstract}
Conversion of waste lignocellulosic (LC) biomass, a widely-available low-cost feedstock, into value-added biobased chemicals (and biofuels) has been gaining much attention recently. Therefore, the present lignin valorisation study was aimed at developing magnetically-separable highly-active catalysts for hydrodeoxygenation (HDO), also proposing surface chemical kinetics. Five carbonaceous substrate-deposited Ru were synthesised and tested for the HDO of monomer moiety eugenol. Their annealing temperatures differed, specifically between 300 and $750{ }^{\circ} \mathrm{C}$, while one was not subjected to calcination. Experiments revealed the substantial influence of annealing temperature on the product distribution. Namely, fresh nonannealed nanocomposites were not active for hydrogenolysis. By further pretreatment increase, hydrogenation and, exclusively, the deoxygenation of saturated cyclic species, were enhanced, these being more promoted considering rates and yields than commercial carbon-supported ruthenium. Over $80 \mathrm{~mol} \%$ of 4-propyl-cylohexanol and propyl-cyclohexane could be formed over the samples, treated at 500 and $600{ }^{\circ} \mathrm{C}$, for 100 and $125 \mathrm{~min}$, respectively, under $275{ }^{\circ} \mathrm{C}$ and $5 \mathrm{MPa}$ of reactor hydrogen pressure. Interestingly, a notable 4-propyl-phenol amount was produced upon $750{ }^{\circ} \mathrm{C}$ pretreating. The intrinsic microkinetic model, developed previously, was applied to determine relevant turnover parameters. Calculated modelling results indicated a 47- and 10-fold greater demethoxylation and dehydroxylation mechanism ability upon the reheatingpreheating at $600{ }^{\circ} \mathrm{C}$ in comparison to industrial (heterogeneous) $\mathrm{Ru} / \mathrm{C}$.
\end{abstract}

Keywords: biomass-derived chemicals; recyclable ruthenium catalyst; heteroatom removal; hydroprocessing; structure-activity relationship; intrinsic kinetics modelling

\section{Introduction}

Lignocellulosic (LC) biomass is available in the form of agricultural residues, waste streams (pulp, paper, and food industry), wood, and energy crops. It is consisted of cellulose (40-50\%), hemicellulose $(15-30 \%)$, and lignin (15-30\%) [1]. Lignin is a complex heteropolymer which plays several important 
roles in plants like mechanical support to the sap-conducting xylem cells, plant defence against parasitic and enzymatic attacks, seed dispersal, and the formation of an apoplastic diffusion barrier in the roots [2,3]. Its monolignol units are interconnected via different ethers and carbon-carbon bonds ( $\beta-\mathrm{O}-4, \alpha-\mathrm{O}-4$, biphenyl, $\beta-5)$ forming a randomised network by a radical polymerisation in the cell wall [4]. Lignin is a feedstock rich in aromatic functionality and represents a significant portion of the total carbon in biomass [5]. Hence, valorisation of this abundant feedstock is required for improving the economic balance of any biorefinery [1]. Beside lignin's transformation into chemicals (i.e., benzenes, cycloalkanes, phenols, and styrene) comprehensively reviewed by Isikgor and Becer [6], it can also be converted into carbonaceous fibre nanocomposites, and other added value products [7-9]. For instance, Agblevor and Jahromi reported an aqueous phase hydrotreatment of guaiacol forming significant amounts of benzene, toluene, and cyclohexane and minor formation of xylene, phenol, catechol, and anisole over a novel catalyst based on the nickel-impregnated red mud in a one-pot process [10]. The product distribution was similar also at nonaqueous experimental conditions [11].

Over years many catalysts based on transition $(\mathrm{Ni}, \mathrm{Mo}, \mathrm{Cu}, \mathrm{Co}$, and $\mathrm{Fe}$ ) and noble metals ( $\mathrm{Pt}$, $\mathrm{Pd}, \mathrm{Rh}$, and $\mathrm{Ru}$ ) have been tested for LC biomass valorisation. Heterogeneous catalysis simplifies the separation of the liquid products from the solid catalyst and its recycling. However, the separation by filtration or centrifugation can be often difficult, especially when the catalyst is in powder form. The use of magnetically separable catalysts helps to overcome these obstacles since they can be easily and efficiently removed from reaction mixtures by applying an external magnetic field gradient [12]. Liu et al. [13] have synthesised magnetic nitrogen-doped carbon-supported cobalt nitride (CoNx@NC) and tested it for HDO of eugenol. They demonstrated different activity and selectivity of catalysts pyrolysed at various temperatures $\left(500-800{ }^{\circ} \mathrm{C}\right)$. More literature is available for conversion of cellulose derivatives over magnetic catalysts such as sulphonated mesoporous silica $\left(\mathrm{Fe}_{3} \mathrm{O}_{4}-\mathrm{SBA}-\mathrm{SO}_{3} \mathrm{H}\right)$, Co-based sulphonated silica $\left(\mathrm{CoFe}_{2} \mathrm{O}_{4} @ \mathrm{SiO}_{2}-\mathrm{SO}_{3} \mathrm{H}\right)$, core-shell structured $\mathrm{Fe}_{3} \mathrm{O}_{4} @ \mathrm{C}-\mathrm{SO}_{3} \mathrm{H}$, and magnetic biocatalysts (enzymes immobilised on a magnetic support) [13]. Magnetically separable carbon supports can be prepared by impregnation of carbon material with magnetic nanoparticles, or to form carbon material in the presence of magnetic nanoparticles and thus incorporating them within the carbon support. The carbon support is usually prepared by pyrolysis of organic precursors, e.g., carbohydrates at 450 to $1500{ }^{\circ} \mathrm{C}$ [14]. In this work the magnetically separable carbon support was prepared by hydrothermal treatment of glucose in the presence of magnetic nanoparticles followed by annealing in an inert atmosphere. $\mathrm{Ru}$ nanoparticles were deposited on the surface of the support in a subsequent step. This work emphasized on the influence of annealing at four different temperatures (none, 300, 500, 600, and $750{ }^{\circ} \mathrm{C}$ ) on catalytic hydrotreatment activity for lignin-derived monomer compound eugenol. The aim of this work is to quantitatively determine the structure-activity correlation based on the thorough catalyst characterization and kinetic parameters determined by the microkinetic model, presented in our previous work [15]. Synthesised catalysts have not been tested in a mixture of several model compounds or actual lignin bio-oil at this level of the research; although it is expected to be implemented in the future work. It is of course important that catalysts retain activity and selectivity, not only in contact with a single reactive molecule, but also in a mixture of model compounds (simulating lignin derived bio-oil mixture) or for the actual lignin-derived bio-oil. However, eugenol has been chosen as a model compound as it contains hydroxy, methoxy, and allyl functional groups on an aromatic ring that are all also present in lignin monomers. Hence the HDO of eugenol yields several products which can be formed during the lignin depolymerisation and further upgrading of building blocks and are also representative from the group-complexity point of view. Additionally, the focus of the present study is primarily a kinetic study, which might be difficult in the case of complex feedstock and corresponding reaction mechanism. This can result in misconclusions and related irrelevance of the determined kinetic parameters. For that reason, the presents study only provides a starting point for further investigation on a real lignin-derived bio-oil. Agblevor and Jahromi, for example, have not observed a significant 
difference in reactivity when the hydrotreatment of model compounds or real biomass pyrolysis oil was investigated [16].

\section{Model}

A detailed model development has been presented in our previous study [15], therefore only a brief model presentation is provided in Supplementary Information. The model is aimed to describe the complex behaviour of a three-phase slurry reactor without predetermination of the rate limiting steps by taking into account phenomena such as hydrogen dissolution in the liquid phase, transport through the films around bubbles and catalyst particles, reactions in the liquid phase, adsorption and desorption of the components, and chemical transformations of adsorbed species. The reactor geometry, process conditions (actual temperatures and pressures, mass of the catalyst, initial reactant concentration, stirring rate, and reaction time), and the catalyst's characteristics (e.g., concentration of active sites and specific surface area) are also involved in the model formulation. Absence of the mass transfer limitations has been assured by intensive mixing, as it has been quantitatively shown in the previous study [15]. Heat transfer effects are likely to be absent considering several aspects commented in detail in our previous work [15]. Specifically, according to the Prater criterion (lower than 1), absence of temperature gradient within the catalyst particles was confirmed.

\section{Results and Discussion}

\subsection{Catalyst Characterization}

Each catalyst is composed of three distinctively different phases of magnetic nanoparticles (first phase) incorporated within the carbonaceous matrix (second phase) representing together a magnetically separable support for $\mathrm{Ru}$ nanoparticles (third phase). X-Ray Diffraction (XRD) patterns (Figure 1) of $\mathrm{Ru} / \mathrm{C}-\mathrm{Fe}_{2} \mathrm{O}_{3}, \mathrm{Ru} / \mathrm{C}-\mathrm{Fe}_{2} \mathrm{O}_{3}-300$, and $\mathrm{Ru} / \mathrm{C}-\mathrm{Fe}_{2} \mathrm{O}_{3}-500$ are composed only of reflections characteristic of magnetic iron oxide and a broad hump at low angles characteristic of amorphous material. Average crystallite size of the iron oxide nanoparticles was found to be approx. $14 \mathrm{~nm}$. XRD pattern of the $\mathrm{Ru} / \mathrm{C}-\mathrm{Fe}_{2} \mathrm{O}_{3}-600$ shows an additional weak reflection, a characteristic of nonmagnetic iron oxide $\mathrm{FeO}$ and $\mathrm{BCC}$ Fe indicating partial reduction of iron oxide. The composition of the $\mathrm{Ru} / \mathrm{C}-\mathrm{Fe}_{2} \mathrm{O}_{3}-750$ is significantly different. The catalyst is composed of cohenite $\mathrm{Fe}_{3} \mathrm{C}$ and nanocrystalline graphite as main phases and smaller amounts of $\mathrm{BCC} F \mathrm{Fe}$ and magnetic iron oxide. Reflections characteristic of Ru were not observed in any of the XRD patterns suggesting its amorphous state. We can conclude that until $500{ }^{\circ} \mathrm{C}$ was reached the iron oxide nanoparticles remain practically intact. At $600{ }^{\circ} \mathrm{C}$, a slow reduction occurs, and at $750{ }^{\circ} \mathrm{C}$, most of the iron oxide reduces to Fe which substantially transforms to $\mathrm{Fe}_{3} \mathrm{C}$. Reduction is most likely due to $\mathrm{CO}$ that forms during decomposition of carbonaceous matter. More detailed characterisation results for the $\mathrm{Ru} / \mathrm{C}-\mathrm{Fe}_{2} \mathrm{O}_{3}-750$ are available in our previous work [17]. 


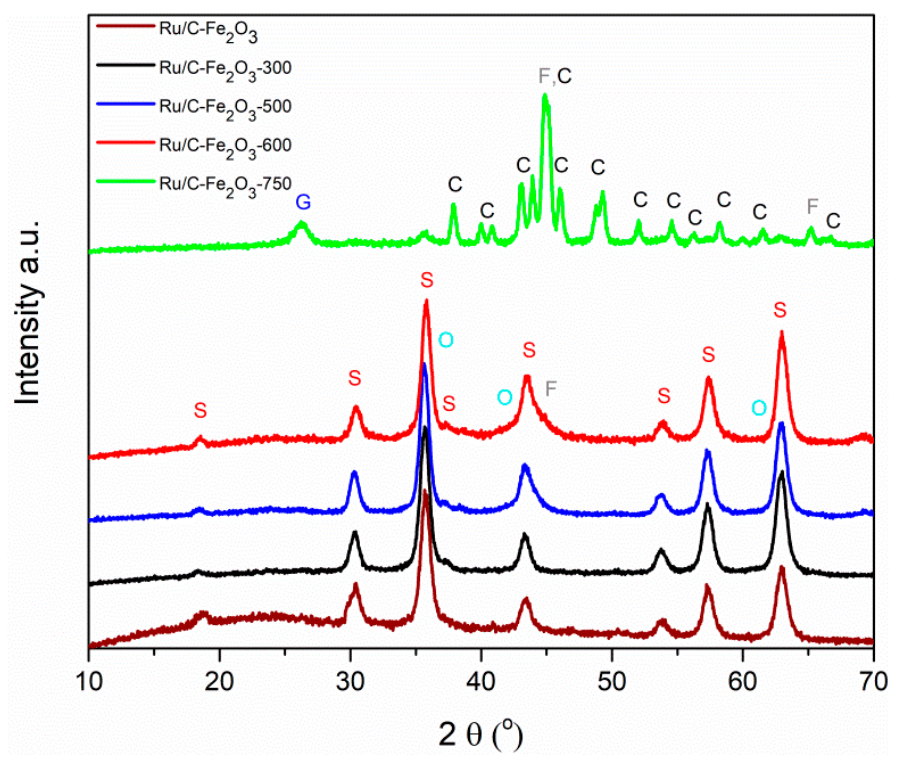

Figure 1. XRD patterns of catalysts. $\mathrm{S}$ corresponds to reflections of cubic spinel-iron oxide, $\mathrm{F}$ of BCC iron, $\mathrm{O}$ of wustite, $\mathrm{C}$ of cohenite, and $\mathrm{G}$ of graphite.

Transmission Electron Microscopy (TEM) imaging of the catalyst particles revealed large differences between them in many aspects, such as distribution of magnetic phases within the carbonaceous matrix, size, and dispersion of the Ru nanoparticles for example (Figure 2). Iron-oxide nanoparticles are visible as dark approximately spherical particles incorporated within the grey matrix of uniform and low contrast (Figure 2a,b). Ru nanoparticles are visible as smaller dark particles seen mostly at higher magnification (Figure $2 \mathrm{~d}, \mathrm{f}, \mathrm{h}, \mathrm{j}$ ). Particles of the catalyst $\mathrm{Ru} / \mathrm{C}-\mathrm{Fe}_{2} \mathrm{O}_{3}$ appear as branched and rounded. Ru nanoparticles are barely visible and their number is relatively low in agreement with observed incomplete reduction of $\mathrm{Ru}^{3+}$. Particles of catalyst $\mathrm{Ru} / \mathrm{C}-\mathrm{Fe}_{2} \mathrm{O}_{3}-300$ appear more compact and covered with $\mathrm{Ru}$ nanoparticles that are predominantly clustered and of relatively broad size distribution (Figure 2c,d and Figure 3, Table 1). It should be mentioned that, also, in this case, the reduction of $\mathrm{Ru}^{3+}$ was incomplete; however, it proceeded much further than in the case of $\mathrm{Ru} / \mathrm{C}-\mathrm{Fe}_{2} \mathrm{O}_{3}$. Particles of $\mathrm{Ru} / \mathrm{C}-\mathrm{Fe}_{2} \mathrm{O}_{3}-500$ are even more compact and completely covered with Ru nanoparticles of largest average size (Figure 2e,f and Figure 3, Table 1). Particles of catalyst $\mathrm{Ru} / \mathrm{C}-\mathrm{Fe}_{2} \mathrm{O}_{3}-600$ appear similar but less densely covered with Ru nanoparticles (Figure 2g,h). Ru nanoparticles are of two different sizes; smaller spherical and larger plate-like (Figure $2 \mathrm{~h}$ ). In Table 1 and Figure 3 only the size distribution of smaller spherical ones is presented. Larger plate-like nanoparticles are predominantly oriented with the basal plane parallel to the electron beam making estimation of their size unreliable. However, a rough estimation of their thickness is $3 \mathrm{~nm}$ and the diameter of basal plane is $15 \mathrm{~nm}$. TEM analysis of the catalyst $\mathrm{Ru} / \mathrm{C}-\mathrm{Fe}_{2} \mathrm{O}_{3}-750$ reveals rather irregular shape of particles (Figure 2i). Larger $\mathrm{Fe}$ and $\mathrm{Fe}_{3} \mathrm{C}$ nanoparticles of dark contrast are clearly visible within the matrix. Observation at higher magnification revealed that nanoparticles are enclosed with graphitic layer. Ru nanoparticles are homogeneously distributed over the support (Figure 2j). 

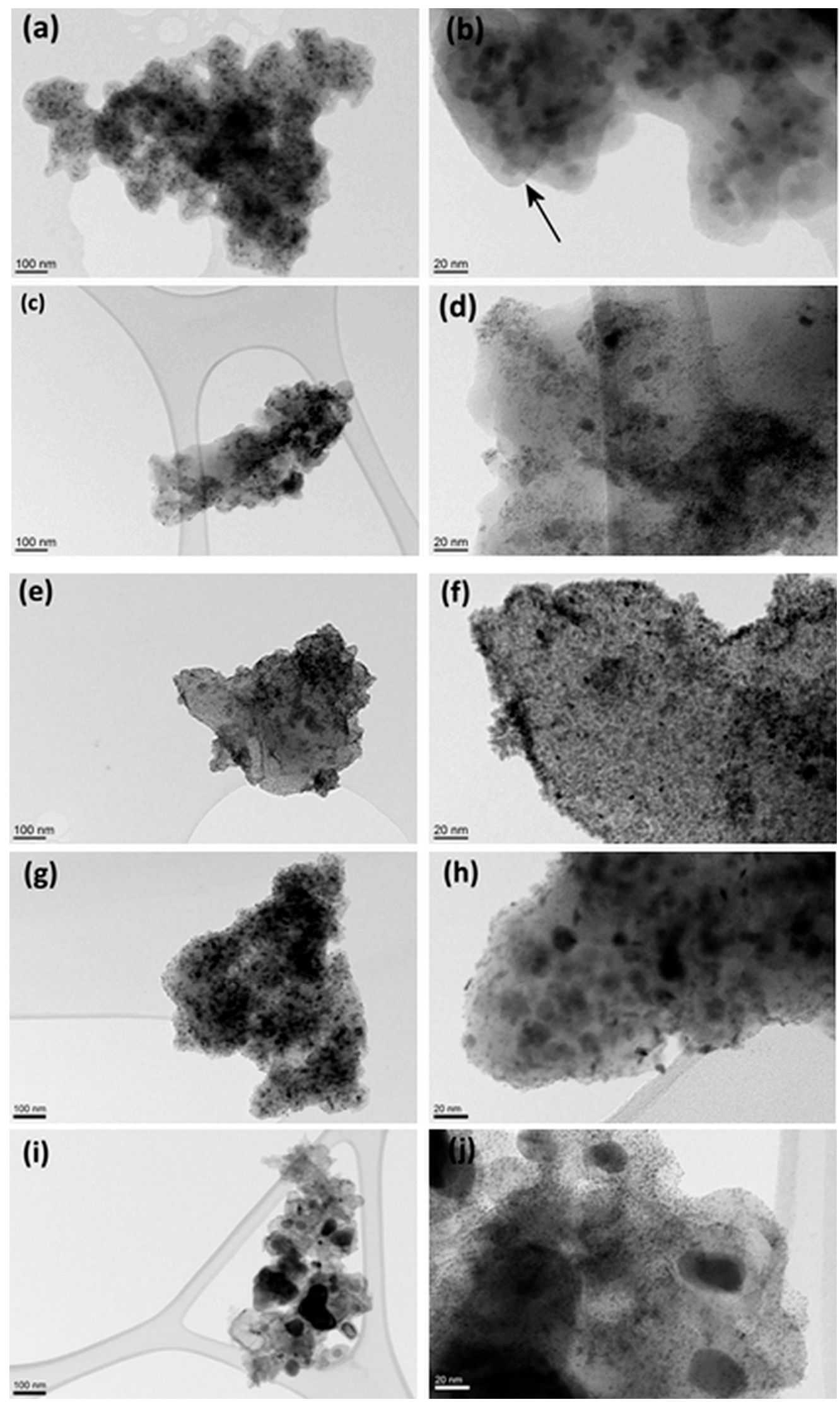

Figure 2. Transmission electron microscopy (TEM) images of catalysts (a,b) $\mathrm{Ru} / \mathrm{C}-\mathrm{Fe}_{2} \mathrm{O}_{3}$, (c,d) $\mathrm{Ru} / \mathrm{C}-\mathrm{Fe}_{2} \mathrm{O}_{3}-300$, (e,f) $\mathrm{Ru} / \mathrm{C}-\mathrm{Fe}_{2} \mathrm{O}_{3}-500$, (g,h) Ru/C-Fe $\mathrm{O}_{3}-600$, and (i,j) $\mathrm{Ru} / \mathrm{C}-\mathrm{Fe}_{2} \mathrm{O}_{3}-750$. An Ru nanoparticle is marked with the arrow ion the image (b). 


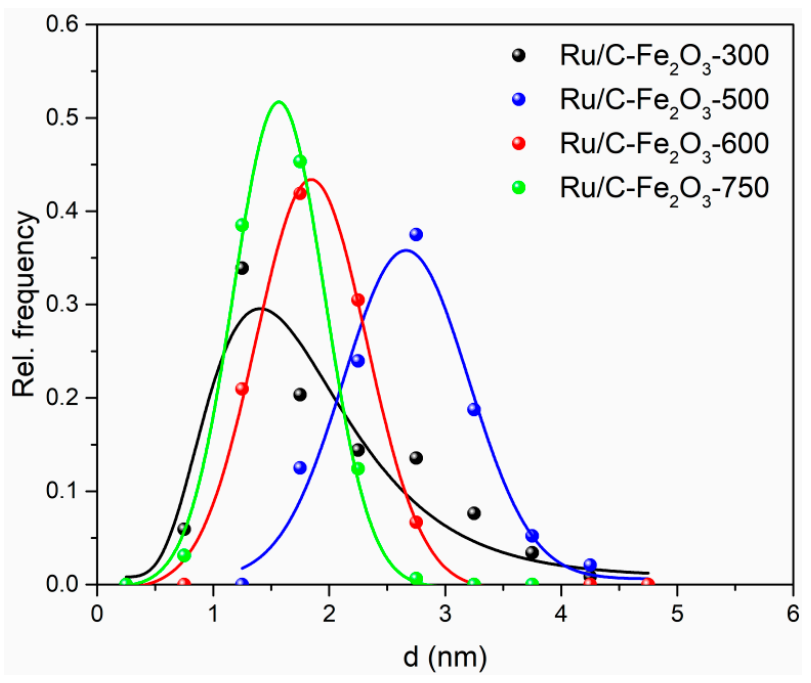

Figure 3. Empirical size distribution of functions of $\mathrm{Ru}$ nanoparticles fitted with Gaussians for the catalysts $\mathrm{Ru} / \mathrm{C}-\mathrm{Fe}_{2} \mathrm{O}_{3}, \mathrm{Ru} / \mathrm{C}-\mathrm{Fe}_{2} \mathrm{O}_{3}-500, \mathrm{Ru} / \mathrm{C}-\mathrm{Fe}_{2} \mathrm{O}_{3}-600, \mathrm{Ru} / \mathrm{C}-\mathrm{Fe}_{2} \mathrm{O}_{3}-750$, and log-normal distribution function for the catalyst $\mathrm{Ru} / \mathrm{C}-\mathrm{Fe}_{2} \mathrm{O}_{3}-300$.

Room-temperature magnetisation curves of the catalysts, except $\mathrm{Ru} / \mathrm{C}-\mathrm{Fe}_{2} \mathrm{O}_{3}-750$, exhibited behaviour characteristic of the superparamagnetic state, namely showing zero coercivity and remanence (Figure 4). Catalyst $\mathrm{Ru} / \mathrm{C}-\mathrm{Fe}_{2} \mathrm{O}_{3}-750$ exhibited ferromagnetic behaviour characteristic of $\mathrm{Fe}_{3} \mathrm{C}[18,19]$. Saturation magnetisation of the catalyst is proportional to the amount of incorporated magnetic nanoparticles. With increased temperature of annealing of the support the saturation magnetisation increased until $500{ }^{\circ} \mathrm{C}$ indicating partial loss of nonmagnetic carbonaceous matter (Figure 4 and Table 1). The drop in saturation magnetisation for the catalyst $\mathrm{Ru} / \mathrm{C}-\mathrm{Fe}_{2} \mathrm{O}_{3}-600$ is related to the formation of nonmagnetic $\mathrm{FeO}$ during annealing of the support at $600{ }^{\circ} \mathrm{C}$ (Figure 1 and Table 1 ). Substantial increase of saturation magnetisation of the catalyst $\mathrm{Ru} / \mathrm{C}-\mathrm{Fe}_{2} \mathrm{O}_{3}-750$ is related to formation of $\mathrm{Fe}$ and $\mathrm{Fe}_{3} \mathrm{C}$ which both display much higher saturation magnetisations than magnetic iron oxide (Figure 1 and Table 1) [18,19]. Magnetic properties of the catalyst assured their rapid separation from reaction mixture using simple permanent magnet (Figure S1).

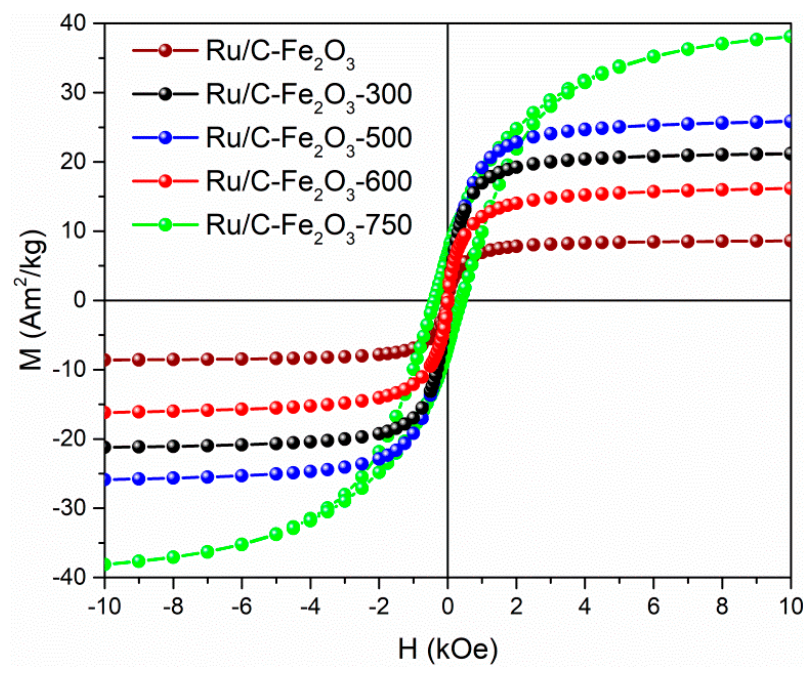

Figure 4. Room-temperature magnetisation curves for the catalysts $\mathrm{Ru} / \mathrm{C}-\mathrm{Fe}_{2} \mathrm{O}_{3}, \mathrm{Ru} / \mathrm{C}-\mathrm{Fe}_{2} \mathrm{O}_{3}-300$, $\mathrm{Ru} / \mathrm{C}-\mathrm{Fe}_{2} \mathrm{O}_{3}-500, \mathrm{Ru} / \mathrm{C}-\mathrm{Fe}_{2} \mathrm{O}_{3}-600$, and $\mathrm{Ru} / \mathrm{C}-\mathrm{Fe}_{2} \mathrm{O}_{3}-750$.

The typical nitrogen adsorption-desorption isotherms of all the catalysts employed in the present study are presented in Figure 5. Catalysts $\mathrm{Ru} / \mathrm{C}-\mathrm{Fe}_{2} \mathrm{O}_{3}, \mathrm{Ru} / \mathrm{C}-\mathrm{Fe}_{2} \mathrm{O}_{3}-300, \mathrm{Ru} / \mathrm{C}-\mathrm{Fe}_{2} \mathrm{O}_{3}-500$, 
and $\mathrm{Ru} / \mathrm{C}-\mathrm{Fe}_{2} \mathrm{O}_{3}-600$ all exhibit Type I isotherms represented by microporous solids, since they are composed of carbonaceous matrix, and thus having a relatively small external surface. This is also typical for activated carbons and zeolites (where the limiting uptake is governed by the accessible micropore volume rather than internal surface area). The result also corroborates well with the TEM micrographs of catalysts (Figure 2a-h), where there is absence of obvious/substantial meso-to-macro porosity in the catalysts. The $\mathrm{Ru} / \mathrm{C}-\mathrm{Fe}_{2} \mathrm{O}_{3}$ catalyst exhibit the shallowest isotherm with the lowest nitrogen uptake, which is directly reflected in the lowest Brunauer-Emmett-Teller (BET) surface area of $8.4 \mathrm{~m}^{2} \mathrm{~g}^{-1}$ and pore volume of $0.089 \mathrm{~cm}^{3} \mathrm{~g}^{-1}$ (Table 1), as a result of low number of barely visible $\mathrm{Ru}$ nanoparticles (Figure 2a,b). The catalyst $\mathrm{Ru} / \mathrm{C}-\mathrm{Fe}_{2} \mathrm{O}_{3}-300$ exhibits an open-like, low pressure hysteresis, extending to the lowest attainable pressures (Figure 5), which was unchanged even after prolonged equilibration time of the measurement ( $240 \mathrm{~s}$ instead of $60 \mathrm{~s}$ ). The phenomenon can in principle be related to the swelling of a nonrigid porous structure, with the irreversible uptake of molecules in pores or an irreversible chemical interaction of the adsorbate with the adsorbent [20]. However, considering the chemical properties of the catalyst $\mathrm{Ru} / \mathrm{Fe}_{2} \mathrm{O}_{3}-300$, the first explanation seems most reasonable. The BET surface area and the pore volume of $\mathrm{Ru} / \mathrm{C}-\mathrm{Fe}_{2} \mathrm{O}_{3}-300$ in comparison to $\mathrm{Ru} / \mathrm{C}-\mathrm{Fe}_{2} \mathrm{O}_{3}$ catalysts were increased to $77 \mathrm{~m}^{2} \mathrm{~g}^{-1}$ and $0.176 \mathrm{~cm}^{3} \mathrm{~g}^{-1}$, respectively (Table 1). The increase can be attributed to the formation of compact clusters of Ru nanoparticles of relatively broad size distribution. By further increase in the annealing temperature of the catalyst preparation to 500 and $600{ }^{\circ} \mathrm{C}$, the microporous network channels were seemingly further evolved as evident from the surface properties (Table 1 ). Namely, the BET surface area of $\mathrm{Ru} / \mathrm{C}-\mathrm{Fe}_{2} \mathrm{O}_{3}-500$ and $\mathrm{Ru} / \mathrm{C}-\mathrm{Fe}_{2} \mathrm{O}_{3}-600$ increased to 209 and $259 \mathrm{~m}^{2} \mathrm{~g}^{-1}$, while the pore volume increased to 0.165 to $0.398 \mathrm{~cm}^{3} \mathrm{~g}^{-1}$, respectively. The reason for such increase is twofold. Firstly, it can be associated with the compositional change of the catalysts, with the formation of partly reduced, nonmagnetic iron oxide $\mathrm{FeO}$ and $\mathrm{BCC}$ Fe phases (Figure 1). Secondly, it can be also ascribed to the pronounced formation of $\mathrm{Ru}$ nanoparticles that are, in the case of $\mathrm{Ru} / \mathrm{C}-\mathrm{Fe}_{2} \mathrm{O}_{3}-500$, the largest in average size, more compact, and completely covering the catalyst (Figure 2e,f and Figure 3, Table 1), while in the case of $\mathrm{Ru} / \mathrm{C}-\mathrm{Fe}_{2} \mathrm{O}_{3}-600$ (Figure $2 \mathrm{~h}$ ), they are of two different sizes, i.e., smaller spherical and larger plate-like (Figure $2 \mathrm{~h}$ ). The Type I isotherm of the catalyst $\mathrm{Ru} / \mathrm{C}-\mathrm{Fe}_{2} \mathrm{O}_{3}-750$ annealed at the highest temperatures was the only one to display a typical hysteresis loop at the highest $\mathrm{p} / \mathrm{p}_{0}$ pressures, which is typical for very narrow slit-like pores originating from the aggregates of loosely coherent particles. While on one hand, the formation of well-crystalline cohenite $\mathrm{Fe}_{3} \mathrm{C}$ particles (and nanocrystalline graphite) (Figures 1 and $2 \mathrm{j}$ ) possibly attributed to the lowered BET surface area, i.e., $74 \mathrm{~m}^{2} \mathrm{~g}^{-1}$ (Table 1), on the other hand, the decomposition of carbonaceous matter forming CO could well be responsible for "loosening" of the catalysts, providing an observed hysteresis loop (Figure 5) and a relatively high pore volume of $0.236 \mathrm{~cm}^{3} \mathrm{~g}^{-1}$.

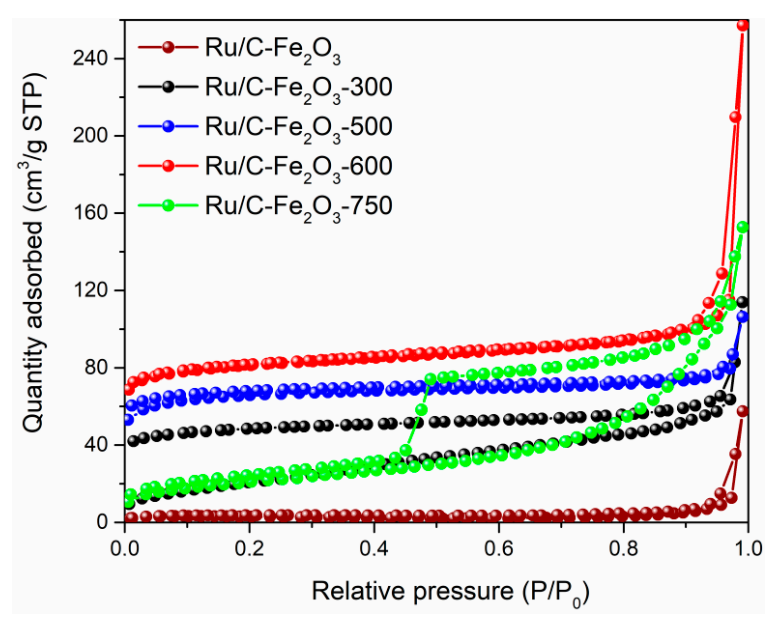

Figure 5. The typical nitrogen adsorption-desorption isotherms of all tested catalysts. 
Table 1. Effect of the annealing temperature on properties of catalysts.

\begin{tabular}{cccccc}
\hline Sample & $\begin{array}{c}\mathbf{M}_{\mathbf{s}} \\
\left(\mathbf{e m u} \mathbf{g}^{-\mathbf{1}} \mathbf{~}^{\mathbf{a}}\right.\end{array}$ & $\begin{array}{c}\boldsymbol{A}_{\mathbf{B E T}} \\
\left(\mathbf{m}^{\mathbf{2}} \mathbf{g}^{-\mathbf{1}} \mathbf{)}\right.\end{array}$ & $\begin{array}{c}\boldsymbol{V}_{\mathbf{p}} \\
\left(\mathbf{c m}^{\mathbf{3}} \mathbf{g}^{-\mathbf{1}} \mathbf{)} \mathbf{b}\right.\end{array}$ & $\begin{array}{c}\boldsymbol{d}_{\mathbf{R u}} \\
\left(\mathbf{n m} \mathbf{c}^{\mathbf{c}}\right.\end{array}$ & $\begin{array}{c}\mathbf{C O}_{(\mathbf{A S})} \\
\left(\mathbf{m o l} \mathbf{g}^{-\mathbf{1}} \mathbf{)}\right.\end{array}$ \\
\hline $\mathrm{Ru} / \mathrm{C}-\mathrm{Fe}_{2} \mathrm{O}_{3}$ & 8.6 & 8.4 & 0.089 & $/$ & $(7.8 \pm 0.1) \times 10^{-5}$ \\
$\mathrm{Ru} / \mathrm{C}-\mathrm{Fe}_{2} \mathrm{O}_{3}-300$ & 21.2 & 77 & 0.176 & $1.9 \pm 0.8$ & $(6.13 \pm 0.08) \times 10^{-5}$ \\
$\mathrm{Ru} / \mathrm{C}-\mathrm{Fe}_{2} \mathrm{O}_{3}-500$ & 25.9 & 209 & 0.165 & $2.7 \pm 0.6$ & $(5.72 \pm 0.03) \times 10^{-5}$ \\
$\mathrm{Ru} / \mathrm{C}-\mathrm{Fe}_{2} \mathrm{O}_{3}-600$ & 16.2 & 259 & 0.398 & $1.8 \pm 0.5^{\mathrm{d}}$ & $(7.77 \pm 0.01) \times 10^{-5}$ \\
$\mathrm{Ru} / \mathrm{C}-\mathrm{Fe}_{2} \mathrm{O}_{3}-750$ & 38.1 & 74 & 0.236 & $1.5 \pm 0.4$ & $(7.6 \pm 0.4) \times 10^{-5}$ \\
\hline
\end{tabular}

${ }^{a}$ Room-temperature magnetisation at $H=10$ kOe. $^{\mathrm{b}}$ Pore volume ${ }^{\mathrm{c}}$ Average diameter of Ru nanoparticles ${ }^{\mathrm{d}}$ Average diameter of small spherical nanoparticles, larger plate-like were excluded.

CO-TPD profiles are provided in Figure 6, while the amount of metal active sites in Table 1. Densities of active sites available for $\mathrm{CO}$ adsorption did not differ much among the catalysts; therefore, very significant differences in catalytic activities might be caused by having fewer active sites available for reactions. It might be worth mentioning that CO-TPD desorption profiles were differing in the number and the shape of peaks among the catalyst as Figure 6 displays. Namely, CO desorption from nonannealed catalyst (wine line) resulted in two observable peaks, one strong at temperatures between 420 and $520{ }^{\circ} \mathrm{C}$ and other low and broad between temperatures 520 and $700{ }^{\circ} \mathrm{C}$. This might indicate the presence of both weak and strong active sites, whereas weak are more dominant. Consequently the catalyst might catalyse various reactions with low activity. For the catalyst treated at $300{ }^{\circ} \mathrm{C}$ (black line), one broad peak, in the temperature range from 490 to $680^{\circ} \mathrm{C}$, was formed. According to the peak shape, one might say that the peak is composed of one sharp peak at $550{ }^{\circ} \mathrm{C}$ and a shoulder at $580{ }^{\circ} \mathrm{C}$. Similar to the first, it could indicate the existence of moderately strong active sites and, therefore, moderate activity for both types of reaction (hydrogenation and deoxygenation). CO desorption from $\mathrm{Ru} / \mathrm{C}-\mathrm{Fe}_{2} \mathrm{O}_{3}-500$ (blue line) resulted in one strong and sharp peak in the range of 450 to $600{ }^{\circ} \mathrm{C}$ and one shoulder in between 600 and $700{ }^{\circ} \mathrm{C}$. Such a CO-TPD profile could again indicate the presence of two types of active sites; moderately strong and dominant and another even stronger but present in small quantities. For the catalyst annealed at $600^{\circ} \mathrm{C}$ (red line), one strong, sharp peak was observed ranging from 420 to $550{ }^{\circ} \mathrm{C}$. Analogously to the previous cases, a single, intensive peak might point to the dominant presence of one type of moderate to strong active site, further indicating higher activity of the catalyst for one or more reactions. The $\mathrm{Ru} / \mathrm{C}-\mathrm{Fe}_{2} \mathrm{O}_{3}-750$ showed one broad, intensive peak ranging from 480 to $680{ }^{\circ} \mathrm{C}$ (green line). The amount of acid active sites, estimated by $\mathrm{NH}_{3}-\mathrm{TPD}$ (Figure S2), varied within experimental error making it difficult to draw a conclusive conclusion.

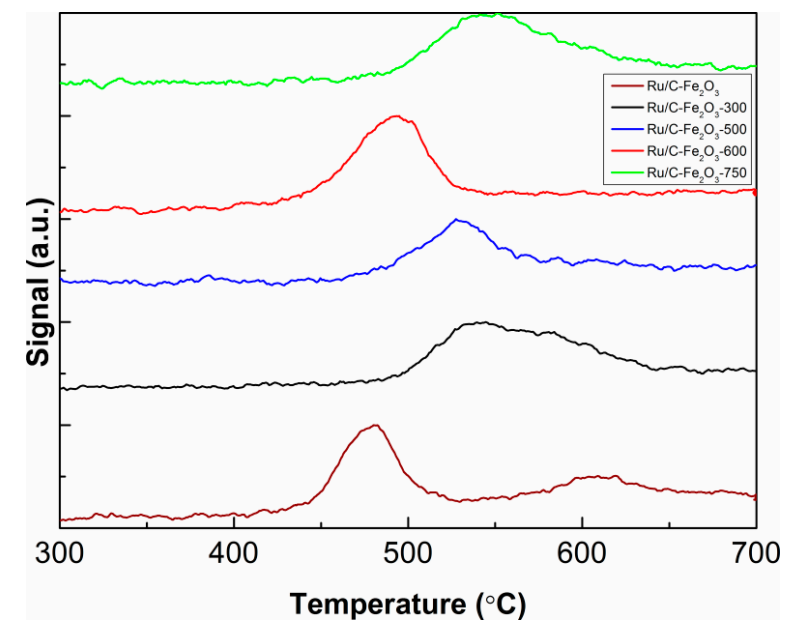

Figure 6. CO-TPD results for $\mathrm{Ru} / \mathrm{C}-\mathrm{Fe}_{2} \mathrm{O}_{3}, \mathrm{Ru} / \mathrm{C}-\mathrm{Fe}_{2} \mathrm{O}_{3}-300, \mathrm{Ru} / \mathrm{C}-\mathrm{Fe}_{2} \mathrm{O}_{3}-500, \mathrm{Ru} / \mathrm{C}-\mathrm{Fe}_{2} \mathrm{O}_{3}-600$, and $\mathrm{Ru} / \mathrm{C}-\mathrm{Fe}_{2} \mathrm{O}_{3}-750$. 


\subsection{Hydrotreatment Results}

The prepared catalysts differed in support annealing temperatures; specifically at 300, 500, 600, and $750{ }^{\circ} \mathrm{C}$, thus catalysts were labelled as: $\mathrm{Ru} / \mathrm{C}-\mathrm{Fe}_{2} \mathrm{O}_{3}-300, \mathrm{Ru} / \mathrm{C}-\mathrm{Fe}_{2} \mathrm{O}_{3}-500, \mathrm{Ru} / \mathrm{C}-\mathrm{Fe}_{2} \mathrm{O}_{3}-600$, and $\mathrm{Ru} / \mathrm{C}-\mathrm{Fe}_{2} \mathrm{O}_{3}-750$. The $\mathrm{Ru} / \mathrm{C}-\mathrm{Fe}_{2} \mathrm{O}_{3}$ label refers to a nonannealed sample. Therefore hypothesis that annealing temperature influenced catalyst activity and selectivity for the hydrotreatment of eugenol was investigated. Detected products in the liquid phase and their abbreviations: eugenol (HMAB), 2-methoxy-4-propylphenol (HMPB), 2-methoxy-4-propycyclohexanol (HMPC), 4-propycyclohexane-1,2-diol (HHPC), 4-propyphenol (HPB), 4-propylcylohexanol (HPC), propylbenzene $(\mathrm{PB})$, propylcyclohexane (PC), propylcyclopentane (PCP), 4-propycyclohexanone (KPC), and isoeugenol (IHMAB). Results are summarized in Figure 7. Nonannealed catalyst showed a very low activity, as it can be seen in Figure 7a. HMAB was fully, but mostly homogeneously (noncatalytically), converted to HMPB within the heating period of the experiment according to the previous results [15] obtained without the catalyst. Further catalytic conversion of HMPB was negligible, since only approximately $2 \mathrm{~mol} \%$ of HPB was observed in the final product, while the mole fraction of other components (HMPC, HHPC, KPC, HPC, and PC) was less than $1 \mathrm{~mol} \%$ each. On the other hand, support annealed at the temperature of $300{ }^{\circ} \mathrm{C}$ significantly increased the final catalyst's activity and selectivity (Figure $7 \mathrm{~b}$ ). Hydrotreatment of $\mathrm{HMAB}$ over $\mathrm{Ru} / \mathrm{C}-\mathrm{Fe}_{2} \mathrm{O}_{3}-300$ after $3 \mathrm{~h}$ resulted in approximately $80 \mathrm{~mol} \%$ of $\mathrm{HPC}, 9 \mathrm{~mol} \%$ of PC, $5 \mathrm{~mol} \%$ of HMPC, $2 \mathrm{~mol} \%$ of PCP and KPC, and $1 \mathrm{~mol} \%$ of PB or HPB. With further annealing temperature increase to $500{ }^{\circ} \mathrm{C}$, catalytic activity was even higher, resulting in enhanced deoxygenation reactions and a higher yield of completely deoxygenated and hydrogenated product PC. $66 \mathrm{~mol} \%$ of $\mathrm{HPC}, 30 \mathrm{~mol} \%$ of $\mathrm{PC}, 2.5 \mathrm{~mol} \%$ of $\mathrm{PCP}$, and a remaining $1.5 \mathrm{~mol} \%$ of others were detected in the final product at $275{ }^{\circ} \mathrm{C}$ (Figure 7d). Higher $\mathrm{Ru} / \mathrm{C}-\mathrm{Fe}_{2} \mathrm{O}_{3}-500$ selectivity towards HPC was accomplished by lowering reaction temperature to $225^{\circ} \mathrm{C}$ (Figure 7c) as a result of the less promoted dehydroxylation reaction. The latter was also noticed based on a notable amount of HHPC in the system (approx. $10 \mathrm{~mol} \%$ ) during a wide reaction time interval. A fraction of this dihydroxyl intermediate was always lower than $4 \mathrm{~mol} \%$ in all other runs. Deoxygenation has been reported as a high activation energy reaction; also confirmed in the present study (see Section 4.3), thus being unfavourable at lower temperatures resulting in low conversion of HPC at $225^{\circ} \mathrm{C}$ and therefore low high final yield. The reaction mixture was cooled after $216 \mathrm{~min}$ and again heated up to $225^{\circ} \mathrm{C}$, with the aim to test the ability of correct model response and test eventual catalyst deactivation during the cooling-down and reheating back to reaction temperature. The catalyst treated at $600{ }^{\circ} \mathrm{C}$ has exhibited a significantly enhanced degree of deoxygenation since $80 \mathrm{~mol} \%$ of PC was detected in the final product, $15 \mathrm{~mol} \%$ of PCP, and the remaining $5 \mathrm{~mol} \%$ belonged to others (mostly HPC) (Figure 7e). However, a notable amount of PCP takes side of disadvantage since ring contraction leads to unwanted carbon losses. When the catalyst's support was treated at $750{ }^{\circ} \mathrm{C}$ (Figure 7f), catalytic activity, as well as selectivity, was significantly reduced. Approximately $8.5 \mathrm{~mol} \%$ of HMPB was still presented in the final product which was fully consumed within the first $100 \mathrm{~min}$ of the reaction by other prepared catalysts or $\mathrm{Ru} / \mathrm{C}(5 \mathrm{wt} \% \mathrm{Ru}$, Sigma Aldrich, St. Louis, MO, USA, reference number 206180). Besides $8.5 \mathrm{~mol} \%$ of $\mathrm{HMPB}$, hydrotreatment of $\mathrm{HMAB}$ over $\mathrm{Ru} / \mathrm{C}-\mathrm{Fe}_{2} \mathrm{O}_{3}-750$ resulted in approximately $22 \mathrm{~mol} \%$ of HMPC, $14 \mathrm{~mol} \%$ of HPB, $47 \mathrm{~mol} \%$ of HPC, $6 \mathrm{~mol} \%$ of PC, and $2.5 \mathrm{~mol} \%$ of others. A work by Whiffen and Smith also showed that the catalyst annealing temperature affected the product distribution [21] of 4-methyphenol HDO. Namely, the $\mathrm{Ni}_{2} \mathrm{P}$ catalyst annealed at $550{ }^{\circ} \mathrm{C}$ and displayed the lowest selectivity towards deoxygenated products, while when annealed at $700{ }^{\circ} \mathrm{C}$ displayed the highest. The same group, one year before, published a study again showing an influence of annealing temperature on the product distribution of 4-methylphenol HDO [22] over the MoP-CA (CA-citric acid) catalyst. The MoP-CA has been annealed in a range of temperatures from 500 to $700{ }^{\circ} \mathrm{C}$. The highest conversion was achieved on the catalyst treated at $550{ }^{\circ} \mathrm{C}(71 \%)$, obtaining the lowest yield of toluene. A slightly lower conversion of 4-methylphenol of $58 \%$, but the highest selectivity towards toluene, was accomplished for the catalyst annealed at $500{ }^{\circ} \mathrm{C}$. 
a)

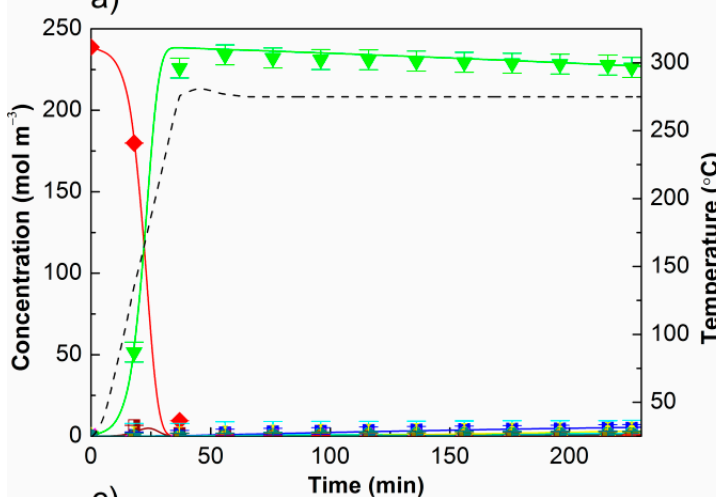

c)

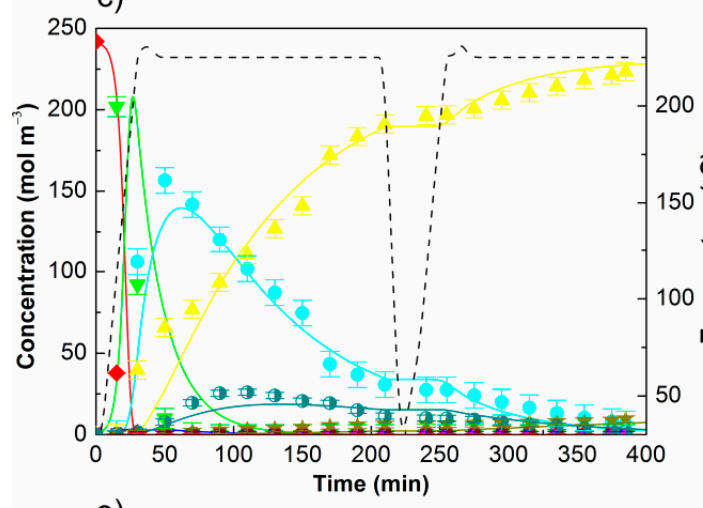

e)

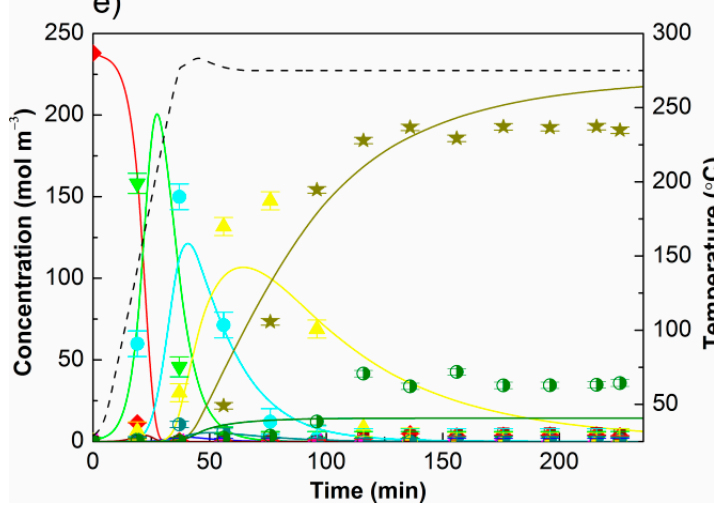

b)

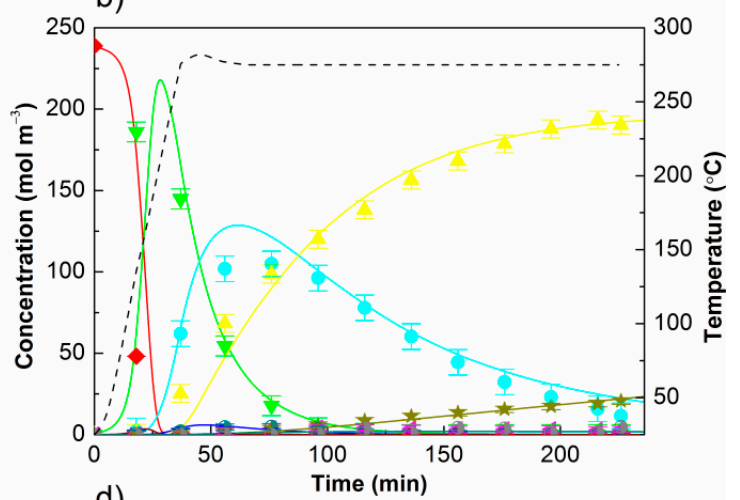

d)
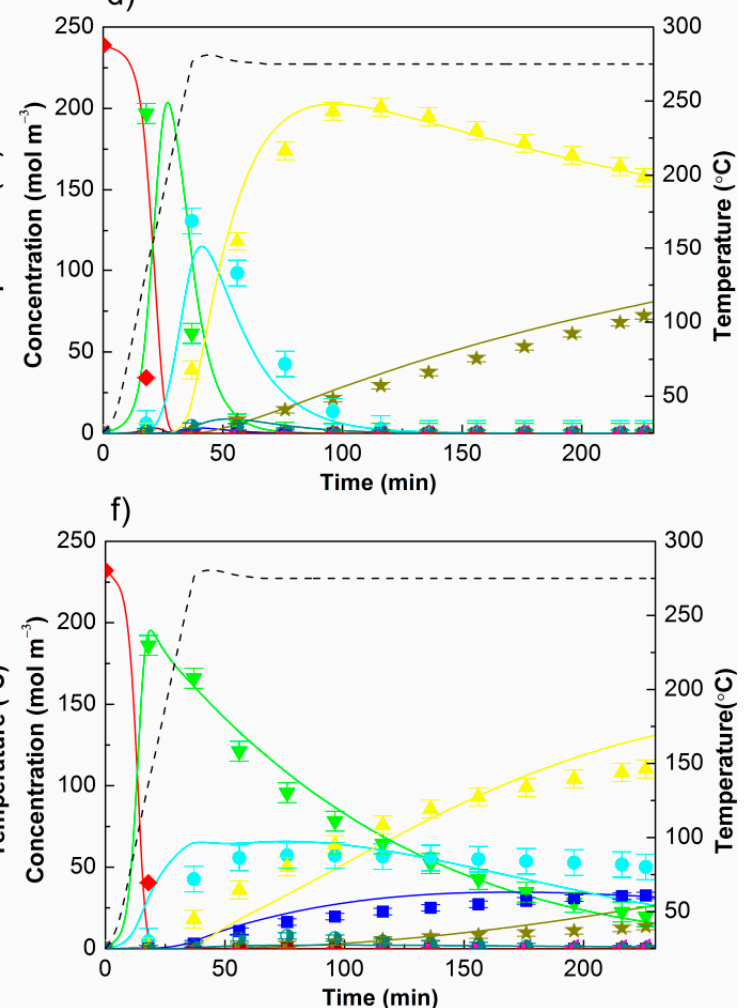

Figure 7. Experimental and model results for (a) $\mathrm{Ru} / \mathrm{C}-\mathrm{Fe}_{2} \mathrm{O}_{3}$, (b) $\mathrm{Ru} / \mathrm{C}-\mathrm{Fe}_{2} \mathrm{O}_{3}-300$, and (c) $\mathrm{Ru} / \mathrm{C}-\mathrm{Fe}_{2} \mathrm{O}_{3}-500$ at $225^{\circ} \mathrm{C}$, (d) $\mathrm{Ru} / \mathrm{C}-\mathrm{Fe}_{2} \mathrm{O}_{3}-500$ at $275^{\circ} \mathrm{C}$, (e) $\mathrm{Ru} / \mathrm{C}-\mathrm{Fe}_{2} \mathrm{O}_{3}-600$ and (f) $\mathrm{Ru} / \mathrm{C}-\mathrm{Fe}_{2} \mathrm{O}_{3}-750$. Meaning of symbols is as follows: $\mathrm{HMAB}, \nabla \mathrm{HMPB}, \mathbf{H P B}^{-\mathrm{HMPC}}, \downarrow \mathrm{PB}, \triangle \mathrm{HPC}, \star \mathrm{PC}, \mathrm{\square}$ IHMAB, $\bigcirc \mathrm{PCP}, \bigcirc \mathrm{HHPC}$,- - temperature.

The reaction network proposed in the previous work [15] for HDO of HMAB over Ru/C has been shown to be valid for magnetic Ru catalysts according to the product evolution and distribution over the reaction time (Figure 8). Several studies proposed reaction mechanisms of lignin model compounds (phenol, m-cresol) HDO over oxophilic metals (e.g., Fe-based catalysts) to describe the observed product distribution $[23,24]$ ruling out direct $\mathrm{Csp}_{2}-\mathrm{O}$ bond scission. Namely, it has been reported that (substituted) phenols might be in an equilibrium with an unstable ketone intermediate (3,5-cyclohexadienol) which can be hydrogenated over an oxophilic catalyst into unsaturated cycloalcohol (3,5-cyclohexadienol). The latter can be readily dehydrated (driven by aromatic stabilization) to (substituted) benzene. However, we have not observed a significant amount of deoxygenated aromatics in contrast to reports on Fe-based catalysts [24-28]. Further comparing our results to those obtained over $\mathrm{Ru} / \mathrm{C}$ ( $5 \mathrm{wt} \% \mathrm{Ru}$, Sigma Aldrich, St. Louis, MO, USA, reference number 
206180) tested in the previous study (Figure S3) [15], one may say that our catalysts performed similar to $\mathrm{Ru} / \mathrm{C}$.

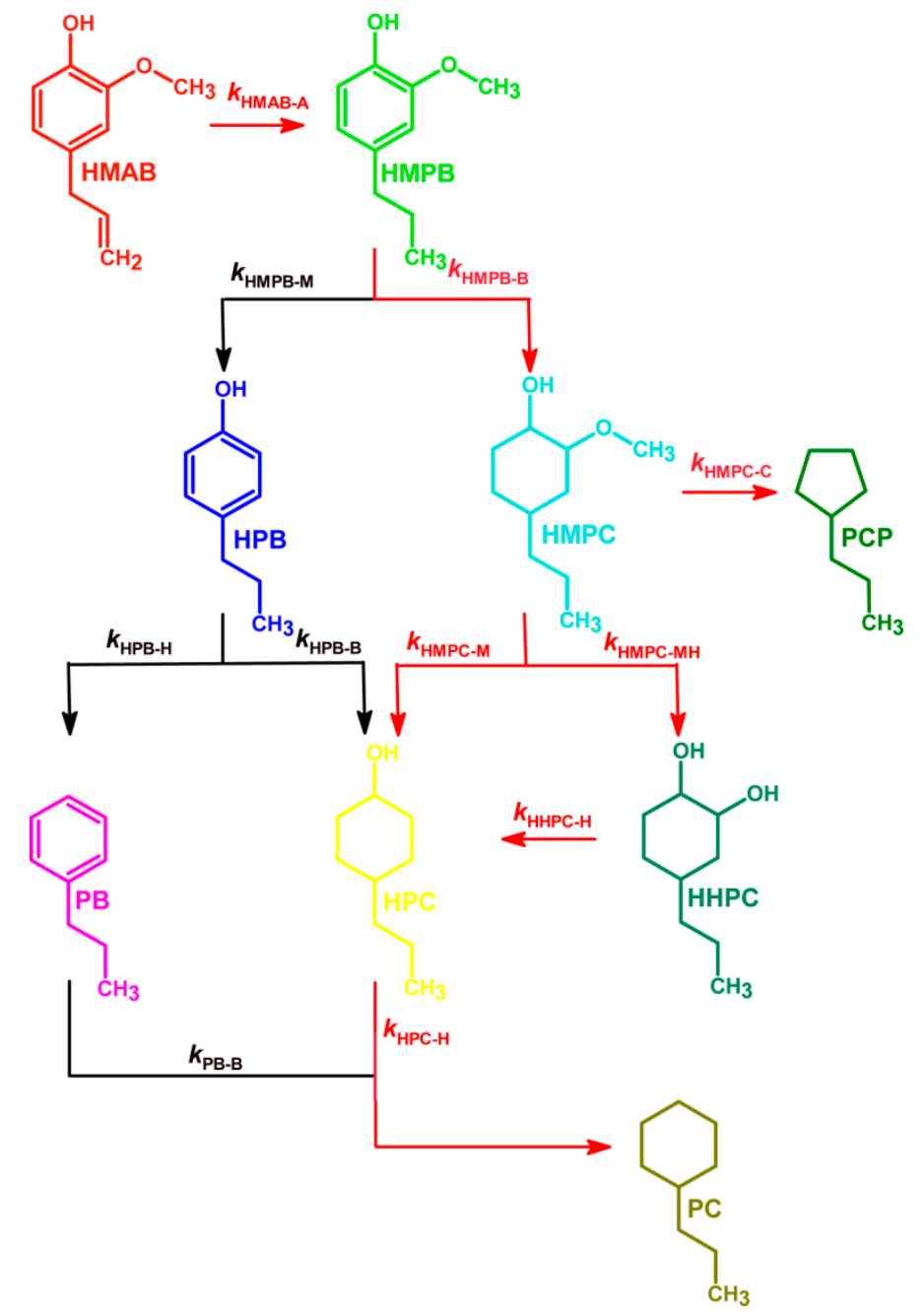

Figure 8. Eugenol reaction network over tested catalysts.

In general, an increase in annealing temperature up to $600{ }^{\circ} \mathrm{C}$ resulted in increasing HDO activity. Although further increase in the annealing temperature to $750{ }^{\circ} \mathrm{C}$ has not provided any improvement in the catalyst activity or selectivity, ring hydrogenation was of lower rate relative to other catalysts causing HPB detection of $14 \mathrm{~mol} \%$ in the final product. Considering significant deviation from the results with Fe-based catalysts, one may say that $\mathrm{Ru}$ is a dominant active phase in our case where ring hydrogenation primarily took place as more favourable due to the planar adsorption of HMAB and HMPB on the Ru surface via ring [29-32]. Enhanced deoxygenation activity of catalysts annealed at higher temperature can be correlated to the dispersion and structure of Ru nanoparticles. Namely, an increase in the number of $\mathrm{Ru}$ nanoparticles (caused by greater reduction of $\mathrm{Ru}^{3+}$ ) and their larger dispersity (according to the XRD and TEM results) is most likely responsible for the increased HDO activity of catalysts annealed at higher temperatures. Nonannealed catalyst possesses a small amount of Ru nanoparticles that are poorly dispersed on the support surface being almost inactive. The number of Ru nanoparticles increased when the catalyst was annealed at $300^{\circ} \mathrm{C}$ showing significantly higher activity compared to nonannealed. Particles were mostly clustered due to the low surface area available for impregnation causing lower activity of this catalyst accompanied by their lower amount compared to those annealed at 500 and $600{ }^{\circ} \mathrm{C}$. When the support was annealed at $500{ }^{\circ} \mathrm{C}$, the number of $\mathrm{Ru}$ nanoparticles increased further, as well as the surface area and thus dispersity. Ru reduction 
proceeded even further when the support was annealed at $600{ }^{\circ} \mathrm{C}$ resulting in a larger number of $\mathrm{Ru}$ nanoparticles with even better dispersity on the support surface (due to even higher surface area), resulting in excellent HDO activity of this catalyst. Two types of particle shape were observed as possibly contributing to such catalytic behaviour, given that different plane might be exposed. A further increase of annealing temperature caused significant structural changes of $\mathrm{Ru} / \mathrm{C}-\mathrm{Fe}_{2} \mathrm{O}_{3}-750$ and, therefore, quite different activity. Considering CO TPD peak's position, it seems that the strength of active sites is mostly moderate for all catalysts, indicating no clear connection between their strength and observed activity. However, the shape could be linked to activity since the most active catalysts (annealed at 500 and $600{ }^{\circ} \mathrm{C}$ ) showed sharp, strong, and narrow peak indicating the dominant existence of one active site type, which might be appropriate for both hydrogenation and deoxygenation. Fe's contribution to enhanced HDO activity is not expected or could be described as minor, as the Fe-phase in our catalysts represents a core coated by a carbon layer. Detailed TEM investigation of the support materials (prior deposition of $\mathrm{Ru}$ ) showed that a small amount of Fe-containing nanoparticles might not be completely coated by a carbon layer when support was annealed at 600 , and particularly, at $750^{\circ} \mathrm{C}$. Ru nanoparticles could be also deposited on these surfaces thus making intimate contact with $\mathrm{Fe}$ which can potentially cause a significant detection of $\mathrm{HPB}$ over $\mathrm{Ru} / \mathrm{C}-\mathrm{Fe}_{2} \mathrm{O}_{3}-750$. Yet this cannot be certainly said as a very thin carbon layer can be still present over the Fe core but not visible on TEM images.

Results over $\mathrm{Ru} / \mathrm{C}$ are shown in supplementary information as Figure S3 (detailed results are available in the previous study) [15]. In both cases, magnetic and commercial $\mathrm{Ru} / \mathrm{C}$, $\mathrm{Ru}$ phase is responsible (or at least mainly) for the observed catalytic activity and is most likely making the difference between them via, for example, the degree of dispersity or the type of Ru active sites exposed. Additionally, the potential impact of Fe might not be ruled out according to the TEM results and estimated acidity of the catalysts. Namely, somewhat higher acidity has been estimated for our catalysts relative to the $\mathrm{Ru} / \mathrm{C}$, which might be expected for Fe-containing catalyst being usually correlated to the grater HDO activity [33-35]. Nevertheless, if there is a Fe contribution, it is probably rather low, as pointed out above.

\subsection{Modelling Results}

Adsorption-desorption equilibrium constants for hydrogen and organic components are estimated to be $3.17 \times 10^{-2}$ and $3.15 \times 10^{-3} \mathrm{~m}^{3} \mathrm{~mol}^{-1}$, respectively. Rate constants of observed reactions and activation energies accompanied are summarized in Tables 2 and 3. It might be worth highlighting that estimated reaction rate constants are already normalized on the concentration of active sites obtained from CO-TPD results being thus a direct indication of catalyst activity. Considering the provided model results, it can be noted that the catalyst's ability to hydrogenate a benzene ring increases with annealing temperature from 0 to $600{ }^{\circ} \mathrm{C}$ by two orders of magnitude between $\mathrm{Ru} / \mathrm{C}-\mathrm{Fe}_{2} \mathrm{O}_{3}$ and $\mathrm{Ru} / \mathrm{C}-\mathrm{Fe}_{2} \mathrm{O}_{3}-300$, 2.5-fold between being annealed at 300 and $500{ }^{\circ} \mathrm{C}$, and 1.3 -fold between being annealed at 500 and $600{ }^{\circ} \mathrm{C}$, decreasing thereafter, as the catalyst annealed at $750{ }^{\circ} \mathrm{C}$ exhibited lower hydrogenation activity compared to other active catalysts, i.e. being between nonactive and annealed at $300{ }^{\circ} \mathrm{C}$. Similarly, the increase of annealing temperature up to $600{ }^{\circ} \mathrm{C}$ facilitated deoxygenation of unsaturated and saturated intermediates (Ar-aromatics, $\mathrm{Al}$-alkyl):

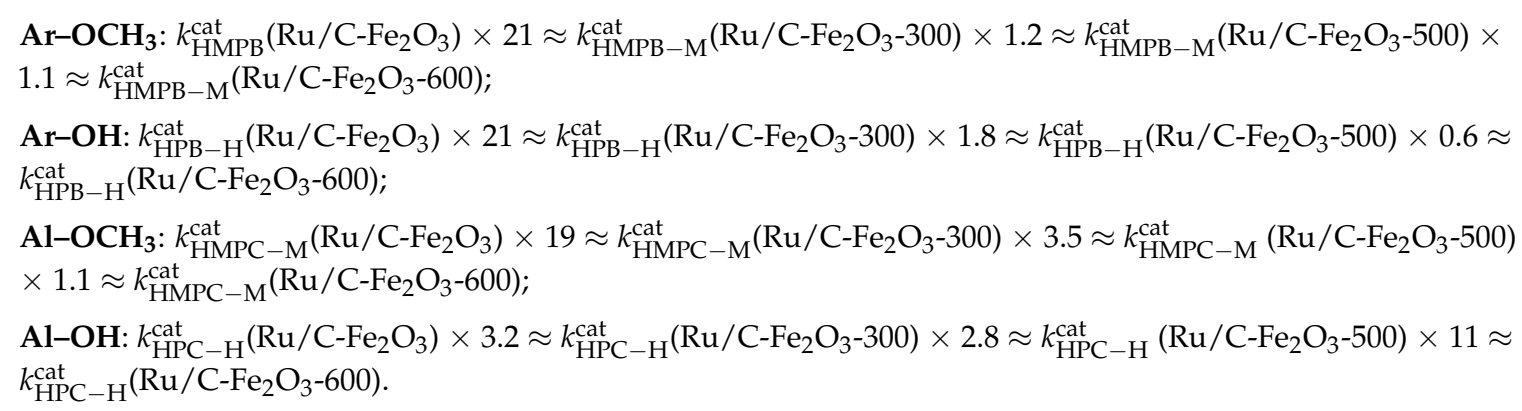


Table 2. Heterogeneous reaction rate constants at $275^{\circ} \mathrm{C}$.

\begin{tabular}{|c|c|c|c|c|c|}
\hline $\begin{array}{c}\text { Reaction Rate } \\
\text { Constant, } \\
\mathrm{m}^{3} \mathrm{~mol}^{-1} \mathrm{~min}^{-1}\end{array}$ & $\mathrm{Ru} / \mathrm{C}-\mathrm{Fe}_{2} \mathrm{O}_{3}$ & $\mathrm{Ru} / \mathrm{C}-\mathrm{Fe}_{2} \mathrm{O}_{3}-300$ & $\mathrm{Ru} / \mathrm{C}-\mathrm{Fe}_{2} \mathrm{O}_{3}-500$ & $\mathrm{Ru} / \mathrm{C}-\mathrm{Fe}_{2} \mathrm{O}_{3}-600$ & $\mathrm{Ru} / \mathrm{C}-\mathrm{Fe}_{2} \mathrm{O}_{3}-750$ \\
\hline$k_{\mathrm{HMAB}-\mathrm{A}}^{*}$ & $5.9 \times 10^{5}$ & $1.3 \times 10^{7}$ & $1.4 \times 10^{7}$ & $1.3 \times 10^{7}$ & $1.3 \times 10^{7}$ \\
\hline$k_{\mathrm{HMPB}-\mathrm{B}}^{*}$ & $1.1 \times 10^{2}$ & $7.2 \times 10^{4}$ & $1.8 \times 10^{5}$ & $2.3 \times 10^{5}$ & $1.5 \times 10^{4}$ \\
\hline$k_{\mathrm{HMPB}-\mathrm{M}}^{*}$ & $2.9 \times 10^{2}$ & $6.3 \times 10^{3}$ & $7.7 \times 10^{3}$ & $8.2 \times 10^{3}$ & $3.2 \times 10^{3}$ \\
\hline$k_{\mathrm{HMPC}-\mathrm{M}}^{*}$ & $1.2 \times 10^{3}$ & $2.3 \times 10^{4}$ & $8.1 \times 10^{4}$ & $9.0 \times 10^{4}$ & $9.3 \times 10^{3}$ \\
\hline$k_{\mathrm{HPB}-\mathrm{B}}^{*}$ & $1.9 \times 10^{2}$ & $1.1 \times 10^{5}$ & $1.8 \times 10^{5}$ & $2.3 \times 10^{5}$ & $2.8 \times 10^{2}$ \\
\hline$k_{\mathrm{HPB}-\mathrm{H}}^{*}$ & $1.5 \times 10^{1}$ & $3.1 \times 10^{2}$ & $5.7 \times 10^{2}$ & $3.3 \times 10^{2}$ & $1.1 \times 10^{2}$ \\
\hline$k_{\mathrm{HPC}-\mathrm{H}}^{*}$ & $4.7 \times 10^{2}$ & $1.5 \times 10^{3}$ & $4.2 \times 10^{3}$ & $4.6 \times 10^{4}$ & $2.7 \times 10^{3}$ \\
\hline$k_{\mathrm{PB}-\mathrm{B}}^{*}$ & $5.3 \times 10^{2}$ & $1.1 \times 10^{5}$ & $1.9 \times 10^{5}$ & $2.9 \times 10^{5}$ & $1.6 \times 10^{5}$ \\
\hline$k_{\mathrm{HMPC}-\mathrm{MH}}^{*}$ & n.a. & $4.3 \times 10^{2}$ & $1.5 \times 10^{4}$ & $1.1 \times 10^{4}$ & $1.2 \times 10^{4}$ \\
\hline$k_{\mathrm{HHPC}-\mathrm{H}}^{*}$ & n.a. & $1.1 \times 10^{4}$ & $1.3 \times 10^{5}$ & $1.8 \times 10^{5}$ & $1.4 \times 10^{5}$ \\
\hline$k_{\mathrm{HMPC}-\mathrm{C}}^{*}$ & n.a. & $7.3 \times 10^{1}$ & $9.8 \times 10^{1}$ & $5.9 \times 10^{3}$ & n.a. \\
\hline
\end{tabular}

Generally, deoxygenation of saturated compounds was more favoured compared to the unsaturated shown also by Goncalves and coworkers [36]. Further, hydrogenation is more favoured than deoxygenation over all tested catalysts being in an agreement with other kinetic studies $[37,38]$. Similar to the results of Massoth et al. [38] and Shafaghat and coworkers [39], we have also observed faster hydrogenation of less substituted benzene. In fact, Massoth et al. reported a hindered hydrogenation of methyl-substituted phenols if the number of methyl groups on the benzene ring was increasing. By investigating the hydrogenation of phenol, cresol, and guaiacol over $\mathrm{Pd} / \mathrm{C}$ and zeolite solid acids, Shafaghat et al. observed a beneficial effect of methyl and methoxy groups in cresol and guaiacol on direct HDO mechanism at the expense of hydrogenation. Removal of oxygen-containing groups takes place to a larger extent via $\mathrm{C}-\mathrm{OCH}_{3}$ bond scission then by $\mathrm{C}-\mathrm{OH}$ cleavage regardless of whether it appears on saturated or unsaturated components. Such behaviour has been also observed by performing DFT calculations of guaiacol HDO over a Ru (0001) plane [30,40].

HMAB transformation into HMPB is a fast reaction over all catalysts tested. The low hydrogenation constant of HMPB for a nonannealed catalyst clearly indicates the low activity of the catalyst. Almost negligible conversion of the first intermediate slows down or disables the downstream reactions. Other tested catalysts have shown good performance in catalysing the ring hydrogenation reaction. A significant amount of $\mathrm{HPC}$ in the system with $\mathrm{Ru} / \mathrm{C}-\mathrm{Fe}_{2} \mathrm{O}_{3}-300$ was a direct consequence of 15 -fold intensive formation than disappearance. This ratio was even larger in the case of $\mathrm{Ru} / \mathrm{C}-\mathrm{Fe}_{2} \mathrm{O}_{3}-500$ (19-fold) resulting in a sharper increase of HPC concentration which started decreasing after $100 \mathrm{~min}$ due to no precursor being formed and a significantly high (higher than for $\mathrm{Ru} / \mathrm{C}-\mathrm{Fe}_{2} \mathrm{O}_{3}-300$ ) rate constant of the disappearance reaction producing a notable amount of oxygen-free component PC. A further increase in the catalyst annealing temperature up to $600{ }^{\circ} \mathrm{C}$ significantly improved catalyst activity in the dehydroxylation of saturated intermediates resulting in a quantitative production of $\mathrm{PC}$ already at $125 \mathrm{~min}$ of the reaction. Only deoxygenation of unsaturated $\mathrm{HPB}$ and formation of HHPC were of lower rate for $\mathrm{Ru} / \mathrm{C}-\mathrm{Fe}_{2} \mathrm{O}_{3}-600$ relative to the $\mathrm{Ru} / \mathrm{C}-\mathrm{Fe}_{2} \mathrm{O}_{3}-500$, all other reaction rates were the highest estimated in this group of catalysts. Catalyst annealed at $750{ }^{\circ} \mathrm{C}$ expressed the lowest hydrogenation activity among all other tested (active). Notable lower activity of $\mathrm{Ru} / \mathrm{C}-\mathrm{Fe}_{2} \mathrm{O}_{3}-750$ to hydrogenate $\mathrm{HPB}$ (over two orders of magnitude lower compared to other active catalysts) accompanied by moderate activity to remove the $\mathrm{OCH}_{3}$ group from $\mathrm{HMPB}$ which caused an appreciable detection of HPB in the system. The ratio between HMPB hydrogenation and demethoxylation clearly indicates the formation of $\mathrm{PC}$ via the hydrogenation route for all catalysts.

Hydrogenation of HMPB was a slightly more promoted reaction on $\mathrm{Ru} / \mathrm{C}-\mathrm{Fe}_{2} \mathrm{O}_{3}-600$, while demethoxylation of HMPC and dehydrohylation of HPC were 47 and 10 times faster reactions, respectively, compared to the $\mathrm{Ru} / \mathrm{C}$ [15]. Demethoxylation of HMPC was also more promoted over $\mathrm{Ru} / \mathrm{C}-\mathrm{Fe}_{2} \mathrm{O}_{3}-750$ in comparison to $\mathrm{Ru} / \mathrm{C}$ (almost five times). $\mathrm{Ru} / \mathrm{C}$ is, however, more active considering all other reactions and the other three tested catalysts in general. 
Activation energies of hydrogenation reactions are significantly lower than for deoxygenation reactions (Table 3). Besides, methoxy group removal is a less energy demanding reaction than the removal of hydroxyl groups, regardless of whether it occurs on a saturated or unsaturated species. Lu et al. [40], in their DFT study, reported an approximately $11 \mathrm{~kJ} \mathrm{~mol}^{-1}$ lower activation energy for guaiacol demethoxylation over the Ru catalyst, and $20 \mathrm{~kJ} \mathrm{~mol}^{-1}$ higher for hydroxyl group removal than estimated in this work. Similarly, $30 \mathrm{~kJ} \mathrm{~mol}^{-1}$ higher activation energy has been observed for m-cresol dehydroxylation $\left(120 \mathrm{~kJ} \mathrm{~mol}^{-1}\right)$ by Tan et al. [9] compared to our estimation for HPB, while it was significantly higher $\left(90 \mathrm{~kJ} \mathrm{~mol}^{-1}\right)$ for its hydrogenation. Higher activation energy of benzene ring hydrogenation $\left(79 \mathrm{~kJ} \mathrm{~mol}^{-1}\right)$ has been also proposed by He et al. but over the $\mathrm{Pd} / \mathrm{C}$ catalyst [41].

Table 3. Activation energies of heterogeneous reactions $\left(\mathrm{kJ} \mathrm{mol}^{-1}\right)$.

\begin{tabular}{cccccc}
\hline$E \mathrm{a}_{\mathrm{HMAB}-\mathrm{A}}^{*}$ & $E \mathrm{a}_{\mathrm{HMPB}-\mathrm{B}}^{*}$ & $E \mathrm{a}_{\mathrm{HMPB}-\mathrm{M}}^{*}$ & $E \mathrm{a}_{\mathrm{HMPC}-\mathrm{M}}^{*}$ & $E \mathrm{a}_{\mathrm{HPB}-\mathrm{B}}^{*}$ & $E \mathrm{a}_{\mathrm{HPB}-\mathrm{H}}^{*}$ \\
\hline 37.5 & 31.5 & 79.3 & 61.0 & 28.5 & 90.2 \\
\hline$E \mathrm{a}_{\mathrm{HPC}-\mathrm{H}}^{*}$ & $E \mathrm{a}_{\mathrm{PB}-\mathrm{B}}^{*}$ & $E \mathrm{a}_{\mathrm{HMPC}-\mathrm{MH}}^{*}$ & $E \mathrm{a}_{\mathrm{HHPC}-\mathrm{H}}^{*}$ & $E \mathrm{a}_{\mathrm{HMPC}-\mathrm{C}}^{*}$ & \\
\hline 128.3 & 33.2 & 42.2 & 77.3 & 130.0 & \\
\hline
\end{tabular}

Product distribution has been affected by temperature as shown in Figure $7 \mathrm{c}, \mathrm{d}$, refer to results obtained at 225 and $275^{\circ} \mathrm{C}$ by the same order. Concentration profiles of formed components up to $50 \mathrm{~min}$ of the reaction (basically of hydrogenated products) are similar at these two temperatures, indicating lower activation energies of ring hydrogenation reactions (confirmed by the model results) and, thus, their lower sensitivity to temperature changes. More significant transformations of HMPC into HPC and further into PC at higher temperature, on the other hand, suggests higher activation energies of deoxygenation reactions also predicted by the model. The observation that deoxygenation reactions become more highly promoted at higher temperatures has been reported in numerous studies [12,28].

Catalyst coverage by each component has been estimated for the $\mathrm{Ru} / \mathrm{C}-\mathrm{Fe}_{2} \mathrm{O}_{3}-300$ catalyst and is shown here as Figure 9 to illustrate the model abilities. Subplot a is related to the log scale of the time axis showing actual surface concentrations, while $b$ represents the catalyst coverage by components at three reaction times. According to Figure $9 a$, the dominant surface components, which take up to 10 min of the reaction, are HMAB and the solvent (HD). Ring hydrogenation mostly takes place within this period causing relatively constant and low hydrogen surface concentration, while it increases thereafter. Hydrogen concentration in the liquid phase was calculated according to the actual pressure in the reactor. HPC has become the dominant surface component after $100 \mathrm{~min}$ of the reaction. 


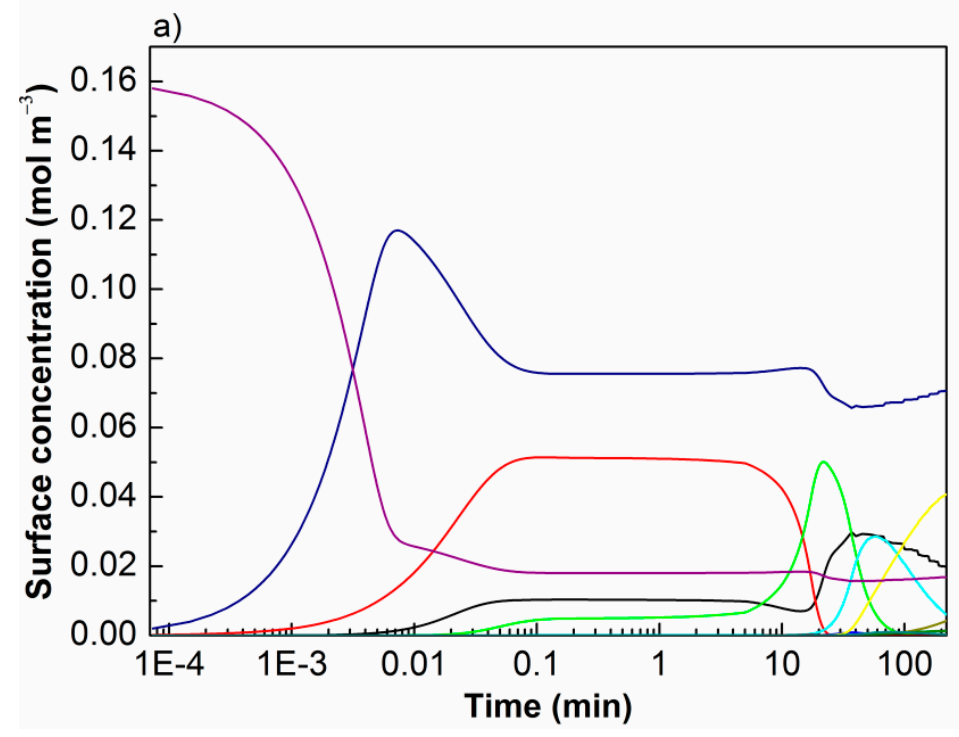

b)

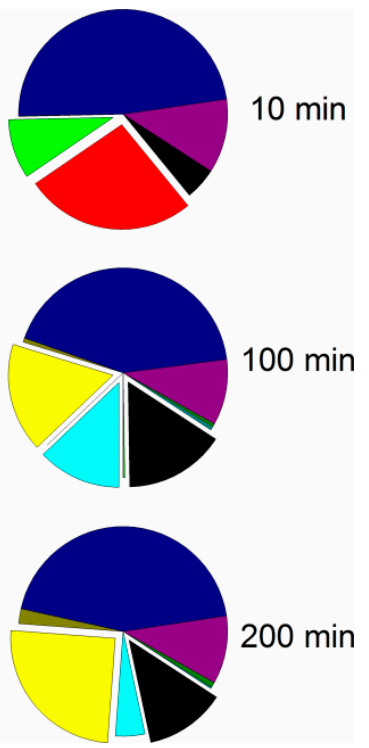

Figure 9. (a) Surface concentration on the $\mathrm{Ru} / \mathrm{C}-\mathrm{Fe}_{2} \mathrm{O}_{3}-300$ catalyst over the entire reaction time presented in log scale (HMAB-red, HMPB-green, HPB-blue, HMPC-cyan, PB-magenta, HPC-yellow, PC-dark yellow, IHMAB-wine, HHPC-dark cyan, hydrogen-black, solvent-navy, vacant active sites-purple); (b) $\mathrm{Ru} / \mathrm{C}-\mathrm{Fe}_{2} \mathrm{O}_{3}-300$ coverage by each component in \% at 10, 100, and $200 \mathrm{~min}$.

\section{Materials and Methods}

\subsection{Catalyst Preparation}

Catalysts were prepared in four steps. In the first step, the citric-acid coated magnetic iron oxide nanoparticles were synthesized by a simple coprecipitation of $\mathrm{Fe}^{2+}$ and $\mathrm{Fe}^{3+}$ ions, followed by citrate ion adsorption [42]. In the second step, glucose was dissolved in the colloidal suspension of citric-acid-coated magnetic iron oxide nanoparticles, transferred to the stainless steel autoclave, and treated at $180^{\circ} \mathrm{C}$ for $12 \mathrm{~h}$. Brown flock $\mathrm{C}-\mathrm{Fe}_{2} \mathrm{O}_{3}$ was washed and dried at $80^{\circ} \mathrm{C}$ in an oven. In the third step, the dried powders $\mathrm{C}-\mathrm{Fe}_{2} \mathrm{O}_{3}$ were heat-treated in a tubular furnace at $300,500,600$, and $750{ }^{\circ} \mathrm{C}$ for $12 \mathrm{~h}$ in $\mathrm{Ar}$ atmosphere. Samples are denoted as $\mathrm{C}-\mathrm{Fe}_{2} \mathrm{O}_{3}-\mathrm{X}$, where $\mathrm{X}$ stands for the heat treatment temperature. Powders were milled as 2-propanol slurries in an agate mill for $2 \mathrm{~h}$. In the fourth step, the obtained suspensions were mixed with the pink solutions of $\mathrm{Ru}$ (III) 2,4-pentadioante in 2-propanol to reach the final concentrations of $1 \mathrm{~g} \mathrm{~L}^{-1}$ of $\mathrm{C}-\mathrm{Fe}_{2} \mathrm{O}_{3}-\mathrm{X}$ and $5 \times 10^{-4} \mathrm{~mol} \mathrm{~L}^{-1}$ of $\mathrm{Ru}^{3+}$. Eight-hundred millilitres of the suspension was transferred to a $1 \mathrm{~L}$ stainless steel Parr autoclave, purged with Ar for $30 \mathrm{~min}$ and, during vigorous stirring, heated to $150{ }^{\circ} \mathrm{C}$ for $10 \mathrm{~min}$. Catalysts $\mathrm{Ru} / \mathrm{C}-\mathrm{Fe}_{2} \mathrm{O}_{3}-\mathrm{X}$ were magnetically separated from the mother liquor, washed 5 times with 2-propanol, and vacuum dried. In the case of $\mathrm{Ru} / \mathrm{C}-\mathrm{Fe}_{2} \mathrm{O}_{3}-500,600$, and 750, the mother liquor was clear and colourless indicating complete reduction and deposition of $\mathrm{Ru}$. More details of the $\mathrm{Ru} / \mathrm{C}-\mathrm{Fe}_{2} \mathrm{O}_{3}-750$ synthesis are provided in the previous work [17]. Based on mass balance, the catalysts contain $5 \mathrm{wt} \%$ of $\mathrm{Ru}$. In the case of $\mathrm{Ru} / \mathrm{C}-\mathrm{Fe}_{2} \mathrm{O}_{3}$ and $\mathrm{Ru} / \mathrm{C}-\mathrm{Fe}_{2} \mathrm{O}_{3}-300$, the mother liquor was clear but pink indicating incomplete reduction of $\mathrm{Ru}^{3+}$. A list of used chemicals in this work is provided in Supplementary information.

\subsection{Catalysts Characterization}

X-ray powder diffraction (XRD) was used to check the phase composition (Siemens D5005 diffractometer with a monochromator in the diffracted beam, Aubrey, TX, USA). Transmission electron microscope (TEM) (Jeol JEM-2100 operated at $200 \mathrm{kV}$ and equipped with JED 2300 EDXS spectrometer, Aubrey, TX, USA) was used to observe catalysts, deposited on a copper-grid-supported lacy carbon foil. Nitrogen adsorption/desorption isotherm was measured for the catalysts at liquid-nitrogen 
temperature using a Nova 2000e (Quantachrome, Boynton Beach, FL, USA) nitrogen sorption analyser. Room-temperature magnetisation curves of the catalysts were measured with a Vibrating-sample magnetometer (VSM) (LakeShore 7307 VSM, Westerville, $\mathrm{OH}, \mathrm{USA}$ ). $\mathrm{CO}$ and $\mathrm{NH}_{3}$ temperature programmed desorption (TPD) was carried out using a Micrometrics AutoChem II Chemisorption Analyser (Micrometrics, Norcross, GA, USA) instrument. The methods and characterisation procedure are described in the Supplementary information.

\subsection{Hydrotreatment Test}

Catalyst testing was performed in a $300 \mathrm{~mL}$ volume batch reactor in a completely batch regime. After $0.5 \mathrm{wt} \%$ of a catalyst, $5 \mathrm{wt} \%$ eugenol, and $84.5 \mathrm{wt} \%$ hexadecane was loaded, the reactor was closed. The headspace was filled with hydrogen up to $5 \mathrm{MPa}$. The reaction mixture was subsequently subjected to intensive stirring $\left(1000 \mathrm{~min}^{-1}\right)$. The reaction was started by heating-up the reaction mixture to room temperature and then to $275^{\circ} \mathrm{C}$ at a rate of $7.5 \mathrm{~K} \mathrm{~min}^{-1}$. After reaching the temperature plateau, the experiment proceeded for $3 \mathrm{~h}$. Liquid phase sampling took place in $20 \mathrm{~min}$ intervals at final temperature with one additional sample in the middle of the heat-up ramp. Gas phase samples were taken in 30 min intervals from the reached plateau onwards. Gas phase composition was determined online using gas chromatography (SRI 8610C, SRI Instruments, INC, Las Vegas, NV, USA) and Fourier transform infrared (FTIR) spectroscopy (Spectrum 100, Perkin Elmer, Waltham, MA, USA). Liquid phase samples were analysed offline using a gas chromatograph with flame ionization detector (GC-FID) (Thermo Fisher Scientific, Waltham, MA, USA) and gas chromatograph with mass spectrometer detector (GC-MS) (2010 Ultra, Shimadzu, Kyoto, Japan), equipped with $(60 \mathrm{~m} \times 0.25 \mathrm{~mm} \times 0.25 \mu \mathrm{m}$, Zebron ZB-5, Phenomenex, Torrance, CA, USA) capillary column. The methodology of quantitative and qualitative (gas and liquid) sample analysis is presented in our previous publications [15,43,44].

\section{Conclusions}

In this work we synthesised five magnetically separable Ru nanoparticles and tested them for $\mathrm{HDO}$ of the representative lignin monomer model compound eugenol in a batch slurry reactor at $275{ }^{\circ} \mathrm{C}$ and $5 \mathrm{MPa}$ of hydrogen. Prior to Ru impregnation, the support was treated at 0, 300, 500, 600, and $750{ }^{\circ} \mathrm{C}$. Product distribution was significantly affected by the annealing temperature. Experimental results indicate remarkable activity of the synthesised catalysts in the HDO of eugenol which selectivity towards fully deoxygenated products could be easily tuned by carbonising the catalysts at different temperatures. Nonannealed catalyst showed no activity in eugenol HDO reactions. On the other hand, thermally treated materials expressed higher hydrogenation and saturated species deoxygenation activity with the increase of annealing temperature, reaching a maximum of $600^{\circ} \mathrm{C}$. Further increase of annealing temperature has not provided any enhancement in catalytic activity, however, a notable amount of 4-propylphenol intermediate was observed due to less selective ring hydrogenation. Catalyst treated at $600{ }^{\circ} \mathrm{C}$ showed superior catalytic performance in terms of deoxygenation of saturated intermediates in comparison to the commercially available $\mathrm{Ru} / \mathrm{C}$. Ru-phase dispersity and amount of Ru nanoparticles are most likely responsible for the observed activity, while the Fe-phase is believed to not contribute or contribute slightly. The model fitted experimental results very well, more deeply explaining the observed trends from a kinetic point of view. The future work is to be focused primarily on gaining a deeper understanding of the structure-activity relationship for various catalyst properties and by monitoring the effects on product distribution. Furthermore, it might involve an increase of complexity of the reaction mixture to investigate potential cross-interactions of lignin derived bio-oil compounds and their influence on catalyst activity and selectivity. At the very final stage, transfer from the batch to a continuous system will be considered.

Supplementary Materials: The following are available online at http:/ / www.mdpi.com/2073-4344/8/10/425/ s1; list of chemicals used, detailed description of the catalyst characterisation procedures, formulation of the microkinetic model, supplementary figures of catalyst separation, summarized $\mathrm{NH}_{3}-\mathrm{TPD}$ results, and catalytic 
performance of commercial $\mathrm{Ru} / \mathrm{C}$ catalyst. The table with nomenclature used in this work is also provided in the supplementary materials.

Author Contributions: A.B. performed the experiments, obtained the model results, and wrote the original draft paper, M.G. coordinated the work and reviewed and edited the paper, S.G., A.K., and D.M. prepared and characterised the catalysts, S.G. also contributed to the preparation of the original draft, B.L. supervised the work.

Funding: This research was funded by the Slovenian Research Agency (research core funding Nos. P2-0089, P2-0087 and P2-0152) and the Scholarship Fund through the scholarships for study of nationals of Western Balkan states in the Republic of Slovenia (JR 177).

Acknowledgments: The authors acknowledge the financial support from the Slovenian Research Agency (research core funding Nos. P2-0089, P2-0087 and P2-0152) and Scholarship Fund through the Scholarships for study of nationals of Western Balkan states in the Republic of Slovenia (JR 177). The authors also acknowledge the use of the equipment in the Center of Excellence in Nanoscience and Nanotechnology-Nanocenter and the contribution of FPS COST Action FP1306.

Conflicts of Interest: The authors declare no conflicts of interest.

\section{References}

1. Alonso, D.M.; Wettstein, S.G.; Dumesic, J.A. Bimetallic catalysts for upgrading of biomass to fuels and chemicals. Chem. Soc. Rev. 2012, 41, 8075-8098. [CrossRef] [PubMed]

2. Breunig, M.; Gebhart, P.; Hornung, U.; Kruse, A.; Dinjus, E. Direct liquefaction of lignin and lignin rich biomasses by heterogenic catalytic hydrogenolysis. Biomass Bioenergy 2018, 111, 352-360. [CrossRef]

3. Welker, C.; Balasubramanian, V.; Petti, C.; Rai, K.; DeBolt, S.; Mendu, V. Engineering Plant Biomass Lignin Content and Composition for Biofuels and Bioproducts. Energies 2015, 8, 7654-7676. [CrossRef]

4. Zhu, H.; Luo, W.; Ciesielski, P.N.; Fang, Z.; Zhu, J.Y.; Henriksson, G.; Himmel, M.E.; Hu, L. Wood-Derived Materials for Green Electronics, Biological Devices, and Energy Applications. Chem. Rev. 2016, 116, 9305-9374. [CrossRef] [PubMed]

5. Lotfi, S.; Mollaabbasi, R.; Patience, G.S. Kinetics of softwood kraft lignin inert and oxidative thermolysis. Biomass Bioenergy 2018, 109, 239-248. [CrossRef]

6. Isikgor, F.H.; Becer, C.R. Lignocellulosic biomass: A sustainable platform for the production of biobased chemicals and polymers. Polym. Chem. 2015, 6, 4497-4559. [CrossRef]

7. Baker, D.A.; Rials, T.G. Recent advances in low-cost carbon fibre manufacture from lignin. J. Appl. Polym. Sci. 2013, 130, 713-728. [CrossRef]

8. Domenek, S.; Louaifi, A.; Guinault, A.; Baumberger, S. Potential of Lignins as Antioxidant Additive in Active Biodegradable Packaging Materials. J. Polym. Environ. 2013, 21, 692-701. [CrossRef]

9. Tan, Q.; Wang, G.; Nie, L.; Dinse, A.; Buda, C.; Shabaker, J.; Resasco, D.E. Different Product Distributions and Mechanistic Aspects of the Hydrodeoxygenation of m-Cresol over Platinum and Ruthenium Catalysts. ACS Catal. 2015, 5, 6271-6283. [CrossRef]

10. Agblevor, F.A.; Jahromi, H. Aqueous phase synthesis of hydrocarbons from reactions of guaiacol and low molecular weight oxygenates. Chem CatChem 2018, in press. [CrossRef]

11. Jahromi, H.; Agblevor, F.A. Hydrotreating of guaiacol: A comparative study of Red mud-supported nickel and commercial Ni/SiO $2-\mathrm{Al}_{2} \mathrm{O}_{3}$ catalysts. Appl. Catal. A Gen. 2018, 558, 109-121. [CrossRef]

12. Liu, B.; Zhang, Z. Catalytic Conversion of Biomass into Chemicals and Fuels over Magnetic Catalysts. ACS Catal. 2016, 6, 326-338. [CrossRef]

13. Liu, X.; Xu, L.; Xu, G.; Jia, W.; Ma, Y.; Zhang, Y. Selective Hydrodeoxygenation of Lignin-Derived Phenols to Cyclohexanols or Cyclohexanes over Magnetic CoNx@NC Catalysts under Mild Conditions. ACS Catal. 2016, 6, 7611-7620. [CrossRef]

14. Lam, E.; Luong, J.H.T. Carbon Materials as Catalyst Supports and Catalysts in the Transformation of Biomass to Fuels and Chemicals. ACS Catal. 2014, 4, 3393-3410. [CrossRef]

15. Bjelić, A.; Grilc, M.; Likozar, B. Catalytic hydrogenation and hydrodeoxygenation of lignin-derived model compound eugenol over Ru/C: Intrinsic microkinetics and transport phenomena. Chem. Eng. J. 2018, 333, 240-259. [CrossRef]

16. Agblevor, F.A.; Jahromi, H. Aqueous-Phase Synthesis of Hydrocarbons from Furfural Reactions with Low-Molecular-Weight Biomass Oxygenates. Energy Fuels 2018, 32, 8552-8562. [CrossRef] 
17. Gyergyek, S.; Kocjan, A.; Bjelić, A.; Grilc, M.; Likozar, B.; Makovec, D. Magnetically separable Ru-based nano-catalyst for the hydrogenation/hydro-deoxygenation of lignin-derived platform chemicals. Mater. Res. Lett. 2018, 6, 426-431. [CrossRef]

18. David, B.; Schneeweiss, O.; Mashlan, M.; Šantavá, E.; Morjan, I. Low-temperature magnetic properties of $\mathrm{Fe}_{3} \mathrm{C}$ /iron oxide nanocomposite. J. Magn. Magn. Mater. 2007, 316, 422-425. [CrossRef]

19. Freel, J.; Wheeler, B.R.; Galwey, A.K. Kinetic study of the oxidation of the carbides of iron. Trans. Faraday Soc. 1970, 66, 1015-1024. [CrossRef]

20. Sing, K.S.W. Reporting Physisorption Data for Gas/Solid Systems With Special Reference to the Determination of Surface Area and Porosity. Pure Appl. Chem. 2009, 57, 603-619. [CrossRef]

21. Whiffen, V.M.L.; Smith, K.J.; Straus, S.K. The influence of citric acid on the synthesis and activity of high surface area MoP for the hydrodeoxygenation of 4-methylphenol. Appl. Catal. A Gen. 2012, 419, 111-125. [CrossRef]

22. Whiffen, V.M.L.; Smith, K.J. The Effect of Calcination Temperature on the Properties and Hydrodeoxygenation Activity of $\mathrm{Ni}_{2} \mathrm{P}$ Catalysts Prepared Using Citric Acid. In Novel Materials for Catalysis and Fuels Processing; American Chemical Society: Washington, DC, USA, 2013; Volume 1132, pp. 287-300.

23. de Souza, P.M.; Rabelo-Neto, R.C.; Borges, L.E.P.; Jacobs, G.; Davis, B.H.; Sooknoi, T.; Resasco, D.E.; Noronha, F.B. Role of Keto Intermediates in the Hydrodeoxygenation of Phenol over Pd on Oxophilic Supports. ACS Catal. 2015, 5, 1318-1329. [CrossRef]

24. Nie, L.; de Souza, P.M.; Noronha, F.B.; An, W.; Sooknoi, T.; Resasco, D.E. Selective conversion of m-cresol to toluene over bimetallic Ni-Fe catalysts. J. Mol. Catal. A Chem. 2014, 388-389, 47-55. [CrossRef]

25. Hensley, A.J.R.; Hong, Y.; Zhang, R.; Zhang, H.; Sun, J.; Wang, Y.; McEwen, J.-S. Enhanced $\mathrm{Fe}_{2} \mathrm{O}_{3}$ Reducibility via Surface Modification with Pd: Characterizing the Synergy within Pd/Fe Catalysts for Hydrodeoxygenation Reactions. ACS Catal. 2014, 4, 3381-3392. [CrossRef]

26. Hong, Y.; Zhang, H.; Sun, J.; Ayman, K.M.; Hensley, A.J.R.; Gu, M.; Engelhard, M.H.; McEwen, J.-S.; Wang, Y. Synergistic Catalysis between Pd and Fe in Gas Phase Hydrodeoxygenation of m-Cresol. ACS Catal. 2014, 4, 3335-3345. [CrossRef]

27. Li, X.; Zhai, Z.; Tang, C.; Sun, L.; Zhang, Y.; Bai, W. Production of propionic acid via hydrodeoxygenation of lactic acid over $\mathrm{Fe}_{\mathrm{x}} \mathrm{O}_{\mathrm{y}}$ catalysts. RSC Adv. 2016, 6, 62252-62262. [CrossRef]

28. Olcese, R.N.; Bettahar, M.; Petitjean, D.; Malaman, B.; Giovanella, F.; Dufour, A. Gas-phase hydrodeoxygenation of guaiacol over $\mathrm{Fe} / \mathrm{SiO}_{2}$ catalyst. Appl. Catal. B Environ. 2012, 115-116, 63-73. [CrossRef]

29. Garcia-Pintos, D.; Voss, J.; Jensen, A.D.; Studt, F. Hydrodeoxygenation of Phenol to Benzene and Cyclohexane on $\operatorname{Rh}(111)$ and $\operatorname{Rh}(211)$ Surfaces: Insights from Density Functional Theory. J. Phys. Chem. C 2016, 120, 18529-18537. [CrossRef]

30. Huš, M.; Bjelić, A.; Grilc, M.; Likozar, B. First-principles mechanistic study of ring hydrogenation and deoxygenation reactions of eugenol over $\mathrm{Ru}(0001)$ catalysts. J. Catal. 2018, 358, 8-18. [CrossRef]

31. Lee, K.; Gu, G.H.; Mullen, C.A.; Boateng, A.A.; Vlachos, D.G. Guaiacol Hydrodeoxygenation Mechanism on $\mathrm{Pt}(111)$ : Insights from Density Functional Theory and Linear Free Energy Relations. ChemSusChem 2015, 8, 315-322. [CrossRef] [PubMed]

32. Lu, J.; Heyden, A. Theoretical investigation of the reaction mechanism of the hydrodeoxygenation of guaiacol over a Ru(0001) model surface. J. Catal. 2015, 321, 39-50. [CrossRef]

33. Cordero-Lanzac, T.; Palos, R.; Arandes, J.M.; Castaño, P.; Rodríguez-Mirasol, J.; Cordero, T.; Bilbao, J. Stability of an acid activated carbon based bifunctional catalyst for the raw bio-oil hydrodeoxygenation. Appl. Catal. B Environ. 2017, 203, 389-399. [CrossRef]

34. Gonçalves, V.O.O.; Ciotonea, C.; Arrii-Clacens, S.; Guignard, N.; Roudaut, C.; Rousseau, J.; Clacens, J.-M.; Royer, S.; Richard, F. Effect of the support on the hydrodeoxygenation of m-cresol over molybdenum oxide based catalysts. Appl. Catal. B Environ. 2017, 214, 57-66. [CrossRef]

35. Liu, X.; Jia, W.; Xu, G.; Zhang, Y.; Fu, Y. Selective Hydrodeoxygenation of Lignin-Derived Phenols to Cyclohexanols over Co-Based Catalysts. ACS Sustain. Chem. Eng. 2017, 5, 8594-8601. [CrossRef]

36. Gonçalves, V.O.O.; de Souza, P.M.; da Silva, V.T.; Noronha, F.B.; Richard, F. Kinetics of the hydrodeoxygenation of cresol isomers over $\mathrm{Ni}_{2} \mathrm{P} / \mathrm{SiO}_{2}$ : Proposals of nature of deoxygenation active sites based on an experimental study. Appl. Catal. B Environ. 2017, 205, 357-367. [CrossRef]

37. Li, C.-L.; Xu, Z.-R.; Cao, Z.-A.; Gates, B.C.; Petrakis, L. Hydrodeoxygenation of 1-naphthol catalyzed by sulfided Ni-Mo $/ \gamma-\mathrm{Al}_{2} \mathrm{O}_{3}$ : Reaction network. AIChE J. 1985, 31, 170-174. [CrossRef] 
38. Massoth, F.E.; Politzer, P.; Concha, M.C.; Murray, J.S.; Jakowski, J.; Simons, J. Catalytic Hydrodeoxygenation of Methyl-Substituted Phenols: Correlations of Kinetic Parameters with Molecular Properties. J. Phys. Chem. B 2006, 110, 14283-14291. [CrossRef] [PubMed]

39. Shafaghat, H.; Sirous Rezaei, P.; Daud, W.M.A.W. Catalytic hydrogenation of phenol, cresol and guaiacol over physically mixed catalysts of Pd/C and zeolite solid acids. RSC Adv. 2015, 5, 33990-33998. [CrossRef]

40. Lu, J.; Behtash, S.; Mamun, O.; Heyden, A. Theoretical Investigation of the Reaction Mechanism of the Guaiacol Hydrogenation over a Pt(111) Catalyst. ACS Catal. 2015, 5, 2423-2435. [CrossRef]

41. He, J.; Zhao, C.; Lercher, J.A. Impact of solvent for individual steps of phenol hydrodeoxygenation with Pd/C and HZSM-5 as catalysts. J. Catal. 2014, 309, 362-375. [CrossRef]

42. Campelj, S.; Makovec, D.; Drofenik, M. Preparation and properties of water-based magnetic fluids. J. Phys. Condens. Matter 2008, 20, 204101. [CrossRef] [PubMed]

43. Grilc, M.; Likozar, B.; Levec, J. Hydrodeoxygenation and hydrocracking of solvolysed lignocellulosic biomass by oxide, reduced and sulphide form of NiMo, Ni, Mo and Pd catalysts. Appl. Catal. B Environ. 2014, 150-151, 275-287. [CrossRef]

44. Grilc, M.; Likozar, B.; Levec, J. Hydrotreatment of solvolytically liquefied lignocellulosic biomass over $\mathrm{NiMo} / \mathrm{Al}_{2} \mathrm{O}_{3}$ catalyst: Reaction mechanism, hydrodeoxygenation kinetics and mass transfer model based on FTIR. Biomass Bioenergy 2014, 63, 300-312. [CrossRef]

(C) 2018 by the authors. Licensee MDPI, Basel, Switzerland. This article is an open access article distributed under the terms and conditions of the Creative Commons Attribution (CC BY) license (http://creativecommons.org/licenses/by/4.0/). 